OECDpublishing

\title{
AI MEASUREMENT IN ICT USAGE SURVEYS
}

\section{A REVIEW}

\section{OECD DIGITAL ECONOMY} PAPERS

March 2021 No. 308

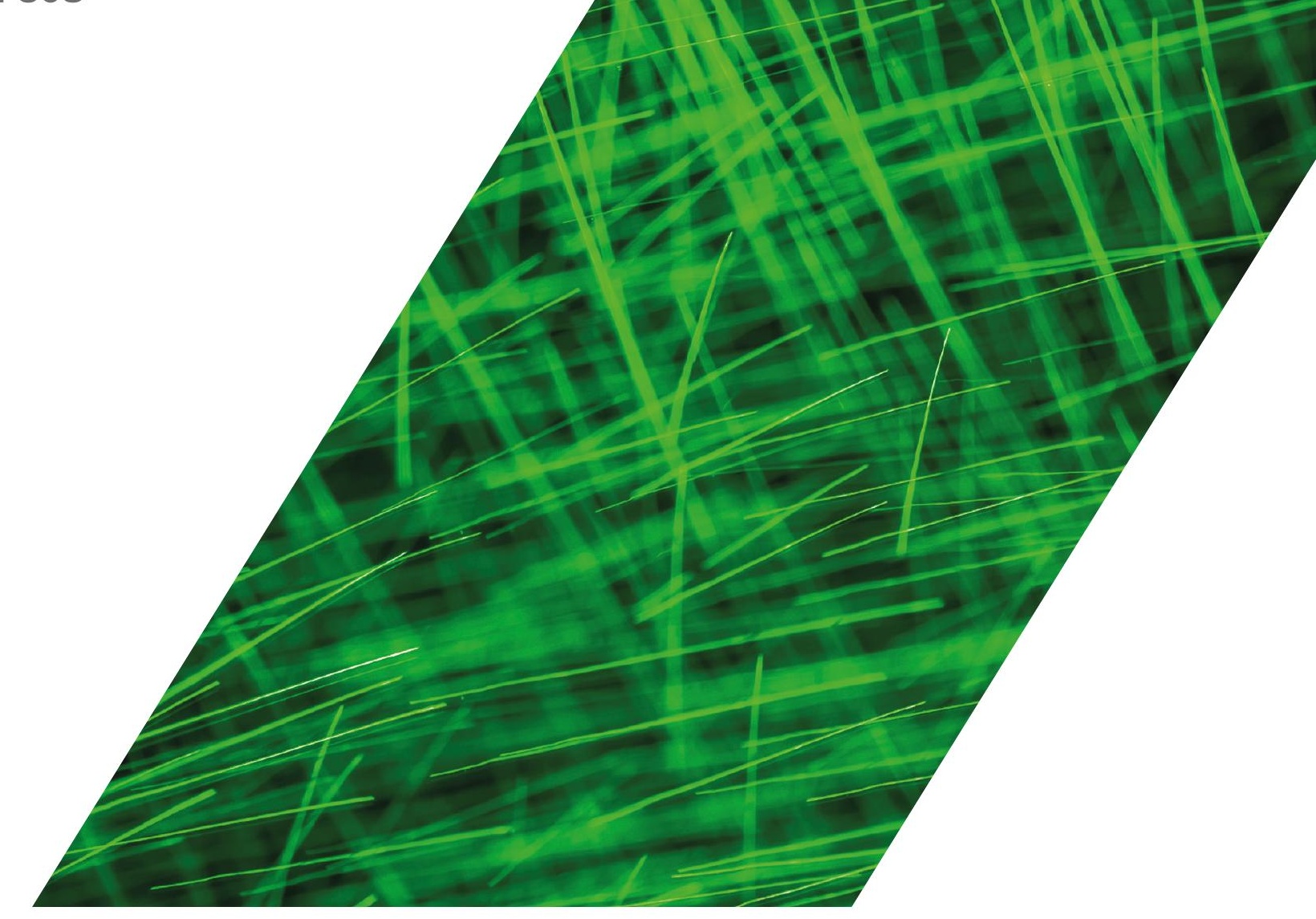




\section{2 | AI MEASUREMENT IN ICT USAGE SURVEYS: A REVIEW}

This paper was prepared by Irene Ek, Swedish Agency for Growth Policy Analysis, and Pierre Montagnier, OECD, under the supervision of the OECD Secretariat. It was approved and declassified by written procedure by the OECD Committee on Digital Economy Policy (CDEP) on 19 November 2020, and prepared for publication by the OECD Secretariat.

This publication contributes to the OECD's Artificial Intelligence in Work, Innovation, Productivity and Skills (AI-WIPS) programme, which provides policymakers with new evidence and analysis to keep abreast of the fast-evolving changes in Al capabilities and diffusion and their implications for the world of work. The programme aims to help ensure that adoption of $A I$ in the world of work is effective, beneficial to all, peoplecentred and accepted by the population at large. AI-WIPS is supported by the German Federal Ministry of Labour and Social Affairs (BMAS) and will complement the work of the German Al Observatory in the Ministry's Policy Lab Digital, Work \& Society. For more information, visit https://oecd.ai/work-innovationproductivity-skills and https://denkfabrik-bmas.de/.

Note to Delegations:

This document is also available on O.N.E. under the reference code:

DSTI/CDEP/MADE(2020)3/FINAL

This document, as well as any data and any map included herein, are without prejudice to the status of or sovereignty over any territory, to the delimitation of international frontiers and boundaries and to the name of any territory, city or area.

The statistical data for Israel are supplied by and under the responsibility of the relevant Israeli authorities. The use of such data by the OECD is without prejudice to the status of the Golan Heights, East Jerusalem and Israeli settlements in the West Bank under the terms of international law.

@ OECD 2021

The use of this work, whether digital or print, is governed by the Terms and Conditions to be found at http://www.oecd.org/termsandconditions. 


\section{Abstract}

This paper takes stock of official statistics on Al use in firms collected through ICT usage surveys. Its aim is to highlight statistically sound data that can be used to guide policymakers and other stakeholders in the complex field of Al. It provides a cross-country comparison of official Al measures in selected OECD countries and international organisations by reviewing the statistical Al definitions developed explicitly for measurement purposes as well as the Al questions in official ICT use surveys. Based on the results of these surveys, the paper provides an international comparison of Al uptake among firms. It also includes a brief overview of smaller-scale non-official measures of Al, which can complement official statistics. In its final part, it makes an initial attempt to match Al policy with the Al measures previously analysed, and highlights possible next steps. This paper is also a contribution to the OECD AI Policy Observatory. 


\section{Synthèse}

Le présent document fait le point sur les statistiques officielles relatives à l'utilisation de l'IA dans les entreprises, collectées au moyen des enquêtes sur l'utilisation des TIC. II vise à mettre en avant des données statistiques de qualité susceptibles de guider les décideurs et autres parties prenantes dans le domaine complexe de l'IA. II propose une comparaison transnationale des mesures officielles de I'IA dans une sélection de pays de l'OCDE et d'organisations internationales; pour ce faire, il passe en revue les définitions statistiques de l'IA formulées à des fins explicites de mesure, ainsi que les questions sur l'IA figurant dans les enquêtes officielles sur l'utilisation des TIC. Faisant fond sur les résultats de ces enquêtes, le document dresse une comparaison internationale de l'adoption de l'IA dans les entreprises. II donne par ailleurs un bref aperçu des mesures de I'IA non officielles, établies à plus petite échelle, qui peuvent être utilisées en complément des statistiques officielles. Enfin, il propose une première tentative de mise en correspondance des politiques en matière d'IA et des mesures de l'IA préalablement analysées, et expose les prochaines étapes envisageables. Ce document contribue également à l'enrichissement de l'Observatoire OCDE des politiques relatives à l'IA. 


\section{Kurzfassung}

Diese Studie liefert eine Bestandsaufnahme amtlicher Statistiken zur KI-Nutzung in Unternehmen, die auf Erhebungen zur IKT-Nutzung beruhen. Ziel ist es, statistisch belastbare Daten hervorzuheben, die Politikverantwortlichen und anderen Akteuren auf dem komplexen Gebiet der KI als Orientierungshilfe dienen können. Um die amtlichen KIMessgrößen verschiedener OECD-Länder und internationaler Organisationen zu vergleichen, werden die statistischen KI-Definitionen, die explizit für Messzwecke entwickelt wurden, sowie die KI-bezogenen Fragen der amtlichen Erhebungen zur IKTNutzung untersucht. Ausgehend von den Ergebnissen dieser Erhebungen präsentiert die Studie einen internationalen Vergleich der KI-Nutzung in Unternehmen. Sie bietet zudem einen Kurzüberblick über kleinere nichtamtliche KI-Erhebungen, die zur Ergänzung der amtlichen Statistiken herangezogen werden können. Abschließend wird ein erster Versuch eines Abgleichs zwischen der KI-Politik und den zuvor analysierten KI-Messgrößen unternommen. Zudem werden mögliche nächste Schritte aufgezeigt. Diese Studie ist ein Beitrag zum OECD Al Policy Observatory. 


\section{Table of contents}

$\begin{array}{ll}\text { Abstract } & 3\end{array}$

$\begin{array}{ll}\text { Synthèse } & 4\end{array}$

Kurzfassung $\quad 5$

Executive Summary $\quad 8$

Résumé $\quad 9$

$\begin{array}{ll}\text { Zusammenfassung } & 10\end{array}$

1 Introduction 11

Outline of the paper 12

2 Cross country comparison of official Al measures 13

Statistical Al definitions commonalities 13

OECD definition 13

Eurostat definition 14

Canada (Statistics Canada, 2019) 14

Denmark (Statistics Denmark, 2019) 14

France (INSEE, 2019) 14

Israel (CBS - Central Bureau of Statistics, 2019) 14

Japan (Communication Usage Trend Survey 2017, Ministry of Internal Affairs and

Korea (2018 yearbook of Information Society Statistics, Ministry of Science and ICT and The

National Information Society Agency) 14

Sweden (Statistics Sweden, 2020)

Towards a conceptual framework for Al 16

Al survey questions cover a wide range of topics 20

Analysis of issues and the level of complexity in Al surveys 20

$\begin{array}{ll}\text { Survey results raises comparison issues } & 27\end{array}$

Explaining the differences: selected possible reasons $\quad 28$ 
3 Examples of non-official Al measures $\quad 29$

4 Matching policy and Al measures $\quad 32$

5 Conclusions and next steps 33

Next steps 33

6 References $\quad 35$

Annex A. Questionnaires 36

Annex B. OECD Al principles $\quad 49$ 


\section{Executive Summary}

Artificial intelligence (Al) is a rapidly evolving area where policy-makers need sound statistical evidence to monitor Al diffusion and assess its effects on the economy and society. The OECD is undertaking several activities to measure Al-related trends. This paper is a contribution to the OECD AI Policy Observatory, which includes the compilation of Al metrics and measurement as one of its four main activities.

The paper starts with a review of statistical Al definitions developed explicitly for measurement purposes. Defining $\mathrm{Al}$ is a complex task, as $\mathrm{Al}$ is often not a standalone technology but is embedded in other technologies. It then analyses the Al questions in official ICT use surveys in seven countries and by two international organisations, pointing out that they cover similar topics but in slightly different ways. Comparability issues raised by different definitions of $\mathrm{Al}$ are compounded by differences in the design, scope and coverage of the surveys across countries. Based on the results of these surveys, the paper provides an international comparison of Al uptake among firms. Al is not anymore an emerging technology, especially among large firms, which are soaring ahead of smaller ones.

An initial attempt is also made to match Al policy with the Al measures previously analysed. Al policy objectives are much broader than what is currently measured in Al surveys, which makes it hard to monitor and evaluate policy in this field.

Finally, the paper points out possible avenues for future work, which include the development of a clear Al measurement agenda, i.e. agreed definitions and methodologies, that enables international comparison especially measures on $\mathrm{Al}$ diffusion in firms, and building a repository of statistically rigorous questions on Al use in firms, in order to showcase quality Al indicators suitable to inform policy. The OECD AI ONE Group of Experts is currently developing a user-friendly framework to classify and help policy makers to better understand $\mathrm{Al}$ systems and the different policy considerations associated with each type of $\mathrm{Al}$ systems. 


\section{Résumé}

L'intelligence artificielle (IA) est un domaine en rapide évolution, et les décideurs ont besoin de données statistiques de qualité pour en surveiller la diffusion et en évaluer les effets sur l'économie et la société. L'OCDE mène actuellement plusieurs activités en vue de mesurer les tendances propres à l'IA. Le présent document contribue à enrichir l'Observatoire OCDE des politiques relatives à l'IA, dont l'une des quatre activités phares porte sur la compilation d'indicateurs et de mesures de l'IA.

Le document passe dans un premier temps en revue les définitions statistiques de l'IA formulées à des fins explicites de mesure. Définir l'IA est une tâche ardue dans la mesure où elle fonctionne généralement comme une technologie, non pas autonome, mais intégrée à d'autres. II analyse ensuite les questions sur I'IA figurant dans les enquêtes officielles sur l'utilisation des TIC de sept pays et deux organisations internationales, soulignant que ces questions abordent des sujets similaires, mais selon des angles qui diffèrent légèrement. Les problèmes de comparabilité liés à l'hétérogénéité des définitions de I'IA sont aggravés par les différences de conception, de portée et de couverture des enquêtes d'un pays à l'autre. Faisant fond sur les résultats de ces enquêtes, le document dresse une comparaison internationale de l'adoption de l'IA dans les entreprises. L'intelligence artificielle n'est plus une technologie émergente, en particulier dans les grandes entreprises, qui font la course en tête loin devant les plus petites.

Le document procède également à une première tentative de mise en correspondance des politiques en matière d'IA et des mesures de I'IA préalablement analysées. Les objectifs des politiques en matière d'IA sont bien plus larges que ce que mesurent actuellement les enquêtes sur l'IA. D'où la difficulté de surveiller et d'évaluer les politiques dans ce domaine.

Enfin, le document expose des pistes envisageables pour la suite des travaux, dont l'élaboration d'un programme clair de mesure de I'IA, avec des définitions et méthodologies concertées, permettant des comparaisons internationales - en particulier des mesures de la diffusion de l'IA dans les entreprises -, et la constitution d'un référentiel de questions rigoureuses d'un point de vue statistique sur l'utilisation de l'IA dans les entreprises, dans le but de fournir des indicateurs de qualité sur l'IA, à même d'éclairer l'élaboration des politiques. Le Groupe d'experts ONE AI de l'OCDE s'emploie actuellement à mettre au point un cadre facile d'utilisation pour classer les systèmes d'IA et aider les décideurs à mieux les comprendre et à appréhender les diverses considérations politiques associées à chaque type de système. 


\section{Zusammenfassung}

Die künstliche Intelligenz $(\mathrm{KI})$ ist ein Gebiet, das sich rasch weiterentwickelt. Die Politikverantwortlichen brauchen belastbare statistische Daten, um die Verbreitung von $\mathrm{KI}$ zu beobachten und ihre wirtschaftlichen und gesellschaftlichen Effekte zu analysieren. Die Messung von KI-Trends ist Gegenstand mehrerer OECD-Initiativen. Diese Studie ist ein Beitrag zum OECD Al Policy Observatory, zu dessen vier Hauptaufgaben die Erfassung von KI-Kennzahlen und -Messgrößen zählt.

Die Studie bietet zunächst einen Überblick über verschiedene statistische KI-Definitionen, die explizit zu Messzwecken entwickelt wurden. Künstliche Intelligenz ist schwer zu definieren, da sie oft nicht als eigenständige Technologie in Erscheinung tritt, sondern in andere Technologien integriert ist. Anschließend werden die KI-bezogenen Fragen analysiert, die in den amtlichen Erhebungen von sieben Ländern und zwei internationalen Organisationen zur IKT-Nutzung enthalten sind. Diese Fragen befassen sich zwar mit ähnlichen Themen, jedoch jeweils auf etwas unterschiedliche Art und Weise. Die Vergleichbarkeit wird nicht nur durch die unterschiedlichen Definitionen von künstlicher Intelligenz erschwert, sondern auch durch Unterschiede bei Konzeption, Umfang und Inhalt der einzelnen Erhebungen. Ausgehend von den Ergebnissen dieser Erhebungen präsentiert die Studie einen internationalen Vergleich der KI-Nutzung in Unternehmen. $\mathrm{KI}$ ist inzwischen keine wirklich neue Technologie mehr. Vor allem aus Großunternehmen, die kleineren in dieser Hinsicht weit voraus sind, ist sie längst nicht mehr wegzudenken.

Es wird auch ein erster Versuch eines Abgleichs zwischen der KI-Politik und den zuvor analysierten KIMessgrößen unternommen. Die Politikziele im Bereich der künstlichen Intelligenz sind wesentlich umfassender als die gegenwärtig in KI-Erhebungen gemessenen Aspekte. Dies erschwert das Monitoring und die Evaluierung der Politik auf diesem Gebiet.

Abschließend nennt die Studie mögliche Themen für zukünftige Arbeiten. Im Einzelnen handelt es sich dabei um die Entwicklung eines zweckmäßigen KI-Messkonzepts, d. h. einheitlicher Definitionen und Methoden, die internationale Vergleiche ermöglichen - insbesondere bei der Messung der KI-Verbreitung in Unternehmen -, sowie die Erstellung eines Katalogs von statistisch adäquaten Fragen zur KI-Nutzung in Unternehmen. Ziel ist es, aussagekräftige KI-Indikatoren zu erhalten, die als Informationsgrundlage für die Politikgestaltung dienen können. Das OECD-Expertennetzwerk für KI (ONE Al) entwickelt gegenwärtig einen nutzerfreundlichen Klassifizierungsrahmen für KI-Systeme. Er soll den Politikverantwortlichen ermöglichen, die verschiedenen Arten von KI-Systemen und die jeweils an sie geknüpften Politikfragen besser zu verstehen. 


\section{Introduction}

Artificial intelligence $(\mathrm{Al})$ is a rapidly evolving area where the OECD emphasises the importance of a collaborative approach to develop trustworthy Al systems for the benefit of society. Several work streams to measure Al-related trends are ongoing across the OECD. This paper is a contribution to the OECD Al Policy Observatory, which includes the compilation of Al metrics and measurement as one of its four main activities (OECD, 2019b).

This paper takes stock of official statistics on Al use in firms collected through ICT use surveys. Its aim is to highlight statistically sound data that can be used to guide policymakers and other stakeholders in the complex field of Al. The paper is also a contribution to the ongoing debate on measurement of Al use in firms.

Established as an academic discipline in the 1950s, Al remained an area of limited interest for over half a century. Today, due to the rise of big data and improvements in computing power, it has entered the business environment and public policy worldwide.

The last two decades have witnessed major advances in Al (Haenlein \& Kaplan, 2019). Future progress is expected to be even more influential, with many studies predicting that these technologies will transform work and business life around the world (Brock \& von Wangenheim, 2019; Garbuio \& Lin, 2019; McKinsey, 2019; PWC, 2018; Ransbotham, Shervin, Fehling, LaFountain, \& Kiron, 2019). At the same time Brynjolfsson, Rock, and Syverson (2017) shows that although systems using Al match or surpass human performance in more and more domains, it does not yet seem to have had a notable impact on productivity growth in the US. The authors put forward four potential explanations for this apparent paradox: false hopes, mismeasurement, redistribution and implementation lags. Furthermore, they perceive implementation lags to be the biggest contributor to the clash of expectations. These explanations suggest that Al capabilities have yet to be diffused widely and full effects will not be realised until waves of complementary innovations are developed and implemented.

Recent studies also highlight that an increasing number of economic models need to be updated in the light of Al-driven automation (Acemoglu \& Restrepo, 2018). Today we are far from a satisfactory understanding of the impact of $\mathrm{Al}$ in the market, and statistically sound measures of Al diffusion and uptake will be essential to help update economic models that in turn can guide policy decisions.

Equally, it is argued that Al will create new opportunities for business value creation and cost reduction (Ransbotham et al., 2019). Nevertheless, as pointed out by the OECD's Al Principles, there are also questions about the trustworthiness of Al systems i.e. the dangers of codifying and reinforcing existing biases (OECD, 2019a). These areas are often not well-captured in official statistics.

Given the potential benefits and the challenges, policy makers need help to develop, implement and improve policies for Al. To do so, it is important to showcase Al measurement efforts to allow countries and stakeholders to engage in a more robust evidence-based discussion of policy responses and to monitor progress in order to develop best practices. This is all the more important as countries launch national Al strategies and need reliable statistics to monitor the effective implementation of these policies, gauge the diffusion and use of $\mathrm{Al}$, and assess effects on the economy and society. 
Lastly, measuring $\mathrm{Al}$ is complex and entails a number of choices that can influence the results. It is important for policy makers and stakeholders that use statistical evidence, in their decision making process, to examine the assumptions on which Al statistics are based..

\section{Outline of the paper}

The paper is organised as follows. Section 1 draws on the latest Al research articles to highlight why it is both problematic and important to measure Al. Section 2 provides a cross-country comparison of official Al measures and is split into three strands. The first strand reviews statistical Al definitions developed explicitly for measurement purposes. Selecting a definition is complex as Al is often not a standalone technology but is embedded in other technologies. In addition, definitions delimit the survey scope and subsequently the results generated. The second strand reviews the Al questions in official ICT use surveys. Based on the results of these surveys, the third strand provides an international comparison of Al uptake among firms. Section 3 provides a brief overview of smaller-scale non-official measures of Al, which can complement official statistics. To highlight how the present AI measures can inform policy, Section 4 makes an initial attempt to match Al policy with the Al measures analysed in this paper. Finally, Section 5 summarises the results and highlights possible next steps. 


\section{Cross country comparison of official Al measures}

\section{Statistical Al definitions commonalities}

Designing Al surveys encompasses a number of choices. To begin with, it is essential to describe as clearly as possible the aspects of $\mathrm{Al}$ that are going to be measured. Because of the speed of Al development and its evolving nature researchers, statistical offices and other stakeholders are struggling with a clear-cut definition of Al. Agreeing on a common definition takes time, which is a challenge in a fast moving area such as Al. An Al definition may need to change as Al use patterns change. For instance, the latest $\mathrm{Al}$ technology patterns differ significantly from previous ones due to the recent surge in machine learning. From SIRI, iOS' virtual assistant, to self-driving cars, Al is progressing rapidly and can encompass anything from Google's search algorithms to IBM's Watson.

Al-based systems are not all directly measureable though its existence often needs to be inferred as it can be software (e.g. voice assistants, image analysis, search engines, and face recognition) or systems embedded in hardware devices (e.g. robots, autonomous cars, drones or loT applications). Selecting a definition is complex as Al is often not a standalone technology but co-exists and is embedded in other technologies.

The following section describe how OECD, Eurostat and statistical offices in different counties define Al and makes a cross-country comparison that highlight recurring terms that signals what $\mathrm{Al}$ is.

\section{OECD definition}

"An Al system is a machine-based system that can, for a given set of human-defined objectives, make predictions, recommendations, or decisions influencing real or virtual environments. Al systems are designed to operate with varying levels of autonomy." (OECD, 2019a)

While OECD provides an Al definition in its May 2019 Council Recommendation on Artificial Intelligence, when it comes to measurement and metrics, there is no official statistical definition of Al.

A statistical Al definition provide information on what to measure and has a direct impact when implementing an Al module within ICT usage survey by businesses. For example Eurostat, in its Community Survey on ICT Usage and E-commerce in Enterprises 2020, decided to use an "embedded approach", namely to include questions on $\mathrm{Al}$ in other relevant modules of the questionnaire such as big data, robotics etc., as the proposed definitions were found too complicated. It also considered that $\mathrm{Al}$ is not a standalone technology but co-exists and is embedded in other technologies. In the meantime, several statistical offices have already decided to implement an AI module within their ICT usage survey (see below). Eurostat will proceed similarly in its 2021 survey.

The existing Al definitions, used as introductory part of the Al modules, are provided below. 


\section{Eurostat definition $^{1}$}

Artificial intelligence refers to systems that use technologies such as: text mining, computer vision, speech recognition, natural language generation, machine learning, deep learning to gather and/or use data to predict, recommend or decide, with varying levels of autonomy, the best action to achieve specific goals.

Artificial intelligence systems can be purely software based, e.g.:

- chatbots and business virtual assistants based on natural language processing,

- face recognition systems based on computer vision or speech recognition systems,

- machine translation software,

- data analysis based on machine learning, etc.

or embedded in devices, e.g.:

- autonomous robots for warehouse automation or production assembly works

- autonomous drones for production surveillance or parcel handling, etc.

\section{Canada (Statistics Canada, 2019)}

Artificial Intelligence (Al) refers to systems that display intelligent behaviour by analysing their environment and taking actions - with some degree autonomy - to achieve specific goals. Al-based systems can be purely software-based or embedded in a device.

\section{Denmark (Statistics Denmark, 2019)}

Machine learning and artificial intelligence includes the use of computer software, which with a starting point in data "thinks", analyzes, problem solves and forms connections in patterns, for instance images, audio and text. It may include computer generated annual report, chat bots or automated marketing.

\section{France (INSEE, 2019)}

Artificial intelligence includes all the technologies aiming at computerization of cognitive tasks traditionally performed by humans: voice recognition, biometrics, image recognition, decision support, etc.

\section{Israel (CBS - Central Bureau of Statistics, 2019)}

Artificial intelligence is that activity devoted to making machines intelligent, and intelligence is that quality that enables an entity to function appropriately and with foresight in its environment

\section{Japan (Communication Usage Trend Survey 2017, Ministry of Internal Affairs and Communications)}

Al (Artificial Intelligence) can be defined as something that can perform, learn, infer, recognize, judge, etc. through data analysis.

Korea (2018 yearbook of Information Society Statistics, Ministry of Science and ICT and The National Information Society Agency)

Artificial intelligence technologies and services are machine-generated intelligence (artificial intelligence)....Refers to a technology that embodies abilities, reasoning skills, perception skills, and natural language comprehension skills......Example) Al assistant service that provides necessary information while 
talking by voice (S Voice and Bixby of Samsung, Q-Voice of LG, Apple's Siri, Google's Now, Microsoft's Cortana, Amazon's Alexa and Echo, SK Telecom's Al Speaker)

\section{Sweden (Statistics Sweden, 2020)}

Artificial intelligence (Al) refers to systems that display intelligent behaviour by analysing their environment and taking actions, with some degree of autonomy, to achieve specific goals. Al based systems can be purely software or embedded in hardware.

Applications for Al can include:

Image and video analysis for diagnostics or facial recognition systems based on computer vision or voice recognition systems:

Machine translation, speech-to-text programs, text analytics or chat robots based on natural language processing;

Decision support, security systems, traffic analysis, fraud detection, recommendation systems, process optimization or recruitment software based on machine learning;

Autonomous drones, self-improving robots for production or warehouse tasks or self-driving vehicles. ${ }^{2}$

To a large extent the Swedish Al definition is based on the definition proposed by the European Commission's high level expert group on AI (EC, 2019). The difference is that Sweden provides the respondent with examples of what $\mathrm{Al}$ applications can include. This was necessary as cognitive tests indicated that it was difficult for respondents with limited previous Al knowledge to know when Al was actually embedded as components of larger system ${ }^{3}$. Respondents needed examples to guide them.

Based on this definition Sweden embedded Al questions in the following already established surveys:

ICT Usage in Enterprises,

ICT Expenditure in Enterprises,

R\&D surveys in BES, GOV and HES.

As the target group covered both public and private sector, it was necessary to change some of the Al application examples in the questions directed towards the public sector. 


\section{Box 2.1. Fact box - Results from cognitive testing in Statistics Sweden}

Statistics Sweden have done cognitive testing of their Al definition. The test included 15 firms of different sizes, regions and industries as well as 5 public sector organisations. The results highlighted differences between industries. Firms in the ICT industry, for example, already had an understanding of AI. In addition, part of the public sector (e.g. medicine) also displayed a greater understanding of Al. In general, the Al definition was well received with only minor misunderstandings. Still, the test did result in a few changes. The example applications and technologies were revised to include areas previously not mentioned (security systems, diagnostics) as well as related Al technologies (machine learning, computer vision etc.). The cognitive testing also show that respondents that did not work directly with ICT or digital services where more prone to focus on the examples rather than the definition itself. This highlight the need to balance examples with the Al definition itself so that respondents do not perceive the examples as a list of requirements.

Further, this cognitive test lend empirical evidence to the importance of specifying what constitutes the use of Al. The Al definition measures intentional use. The respondents are asked to exclude nonintentional Al use such as online search engines, personal virtual assistants and mobile applications. Still, the testing highlight that as many practical Al applications are still in process of being developed it is important to include experimental use and related expenditure.

Statistics Sweden's surveys that include questions on Al use and expenditure target different types of respondents. The respondents encompasses head of IT departments, economic controllers and R\&D specialists. Difficulties regarding tracing Al usage in accounting systems makes it essential to instruct the respondents to ask for help if they are not able to answer the questions themselves.

Source: Text provided by Nils Adriansson at SCB

\section{Towards a conceptual framework for Al}

Introductory definitions of $\mathrm{Al}$ in the questionnaires are not a minor issue. Overall, the propensity of respondent to neglect the texts inserted in the introductory parts of the modules is relatively significant. When needed, a short introductory text may help respondents provide focused and coherent answers. For $\mathrm{Al}$, a short text (e.g. the OECD definition) mirrors a level of abstraction somewhat distant from a concrete implementation dimension. On the other hand, providing examples, while helping respondent to formulate relevant answers in the module, obviously lengthen the introduction. The definitions listed below mirrors the variety of choices made. Are those choices indeed so different? How "close" are the Al definitions listed above from each other? Do they have any similarities, or significant differences?

Based on a set of selected key words or expressions included in the Al definitions, it is possible to provide a comparative analysis, which is summarised in Table 2.1 and developed below. This cross-country text analysis of the Al definition shows common terms that signal what $\mathrm{Al}$ is. Table 2.1 highlights these recurring terms and present an initial attempt to group them together. It shows that the nine available definitions refer to Al in slightly different ways (e.g. some using "system(s)", other using "technologies"). Furthermore, the "intelligence" feature is referred to with different expressions. Only a few include analysis of the environment or the function of prediction and goals, but all definitions explicitly -either in the body text of the definition or in the examples provided- refer to an activity or action, and most of them to machine, devices, or entity. Finally, five out of the nine definitions provide concrete examples of Al implementation.

Some of the Al definitions are more similar. The Eurostat definition is very close to that of OECD, and adds examples organised around two dimensions ("pure software"/"embedded in devices"). Canada and 
Sweden definitions are very close to Eurostat's as they are using the same split for Al systems ("can be purely software-based or embedded in device"). By contrast, they also both explicitly refer to systems that "display intelligent behaviour", not to be found in Eurostat definition.

There are also differences. Some countries (e.g. France, Israel and Japan) provide formulations relatively distant from the OECD definition.

Overall, what distinguish most Al definitions are probably how the "intelligence" is captured and the associated type of actions, the reference to a "various level of autonomy" and to the "environment", as well as the way to deal with examples. 
Table 2.1. A brief review of the official surveys Al definitions singularities

Based on a set of selected key words or expressions in the definitions

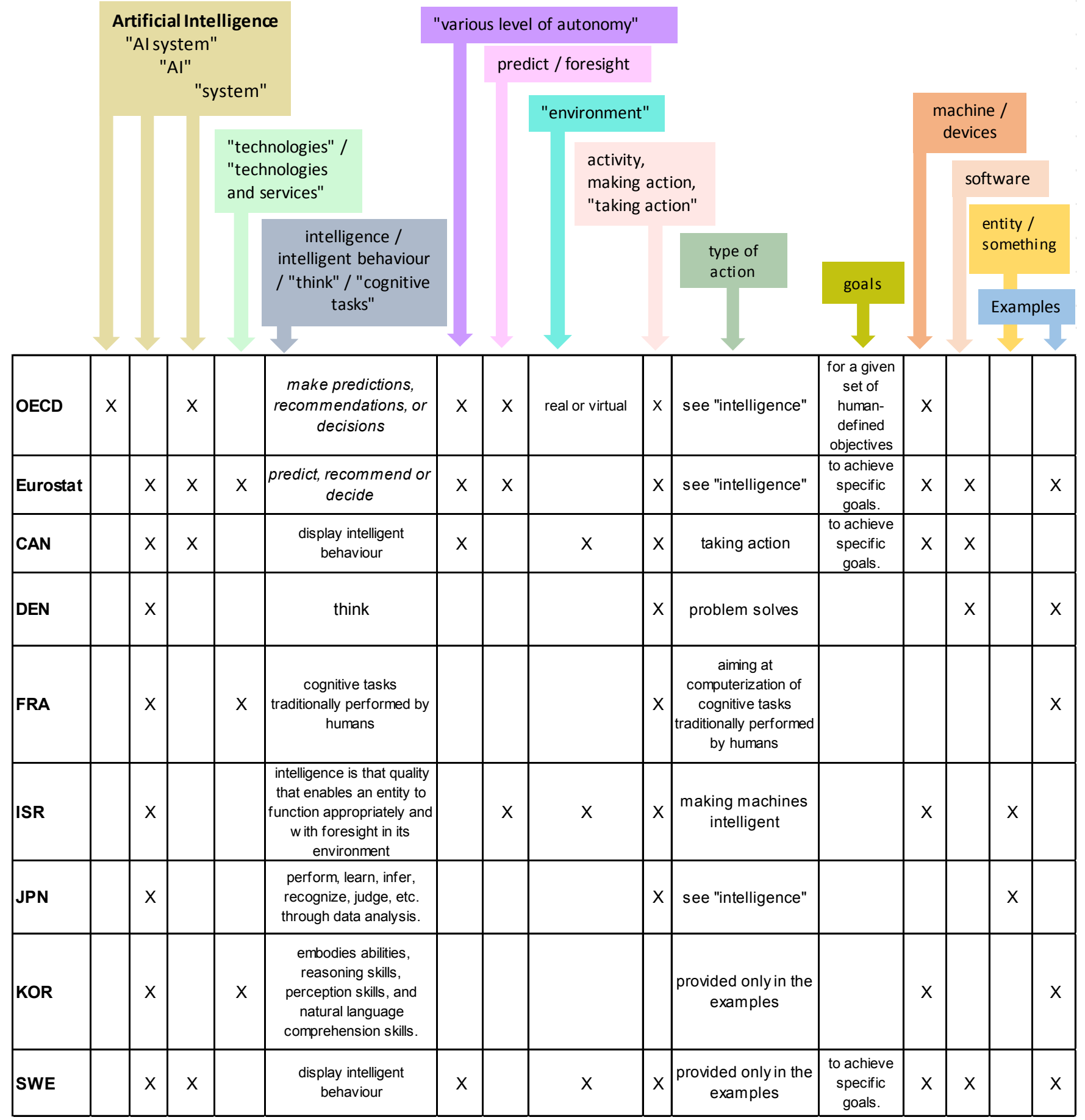

Source: OECD, based on the definitions. 
The following section provide further empirical examples of the recurring terms presented in Table 2.1. These terms signal what $\mathrm{Al}$ is.

\section{Artificial Intelligence}

All definitions include either one or more of the following terms: "Artificial Intelligence" (or simply "Al"), "Al system", "system(s)", "machine-based system", "technologies" or "technologies and services".

\section{Technologies}

Eurostat, France and Korea, refer to $\mathrm{Al}$ as "a technology", or "technologies", or "systems that use technologies". On the other hand, although not using this word in the introductory part of the Al module, Canada clearly classify "Al" within a group of various ICTs (see Annex A).

\section{Intelligence}

The concept of "intelligence" is key topic and treated as follows. Either the word "intelligent/intelligence" is specifically repeated (Canada and Sweden: "...display intelligent behaviour..."; Israel: ..."making machines intelligent"; Korea: “...machine-generated intelligence...”). Alternatively, it is implicitly referred to through an expression or a sentence related to actions (OECD: "make predictions, recommendations, or decisions"; Eurostat: "predict, recommend or decide; Denmark: "thinks", analyses, problem solves and forms connections in patterns"; France: "cognitive tasks traditionally performed by humans"; Israel: "quality that enables an entity to function appropriately and with foresight in its environment"; Japan: "perform, learn, infer, recognize, judge, etc. through data analysis"; Korea: "embodies abilities, reasoning skills, perception skills, and natural language comprehension skills.").

\section{Level of autonomy}

Canada, Sweden and Eurostat are aligned with the OECD definition with respect to the "various levels of autonomy".

\section{Environment}

As in the OECD definition, only three countries (Canada, Israel, and Sweden) explicitly mention the "environment".

\section{Action}

All definitions refer to an activity, to an action, either mentioned in generic terms or provided in detail (see "Intelligence"). Only OECD, Eurostat and Israel specifically mention the predictive dimension ("predict", "prediction", "foresight").

In Korea, the only country where the action or activity related to action is not included explicitly in the definition, examples are used to provide illustrations of actions.

\section{Goals or objectives}

As in the OECD definition, only Canada, Eurostat and Sweden explicitly refer to a set of objectives or to specific goals. 
Machines, devices, software, entity

Those items clearly show the multidimensional nature of Al, which can be embedded in hardware, in machines, in devices, or be purely be software-based, or include both cases. Hence also the use of more fuzzy expressions, such as "entity" or even "something", enlarging the field of potential applications.

\section{Definitions with examples}

Only four countries (Denmark, France, Korea and Sweden) and Eurostat include examples in their definitions.

\section{Al survey questions cover a wide range of topics}

Measures of $\mathrm{Al}$ use in firms has been recently introduced in official statistics and survey vehicles are heterogeneous (e.g. Innovation Surveys, ICT usage surveys, General Business surveys). This paper focus mainly on ICT usage surveys by businesses, except for Canada, where the Survey of Innovation and Business Strategy included a question on Al in 2017 (Statistics Canada, 2018) ${ }^{4}$, and for the United States, where the Annual Business Survey includes a Technology module ${ }^{5}$ since 2017.

Official survey questionnaires tackle the various issues, around Al adoption and uptake, following different approaches. There are many different measurement approaches as Al has the potential to disseminate across the economy. Researchers such as Agrawal, Gans, and Goldfarb (2019) and Le Cun (2020) argues that $\mathrm{Al}$ has such broad application that it qualifies as a general purpose technology. The way businesses are questioned on the Al goes more and less deeply into the complexity of Al being perceived as a generalpurpose technology. Therefore, the structure and the variety of the items covered follow various levels of sophistication according to the countries. This relate for example to items such as the simple usage or adoption status, adoption barriers and obstacles, process of acquisition, types of Al technologies, fields of implementation, skills needed, or impacts.

\section{Analysis of issues and the level of complexity in Al surveys}

Table 2.2 provides an initial cross-country analysis of the issues covered in the Al measures ${ }^{6}$. The table is based on a detailed review of the Al survey questions presented in the following sections. To highlight that this is an initial analysis, and that the Al questions cover more issues than the table can capture, the sections that follows are structured according to the evidence and does not always align with the categories shown in the table. 
Table 2.2. Measurement of Al in official statistics, an overview

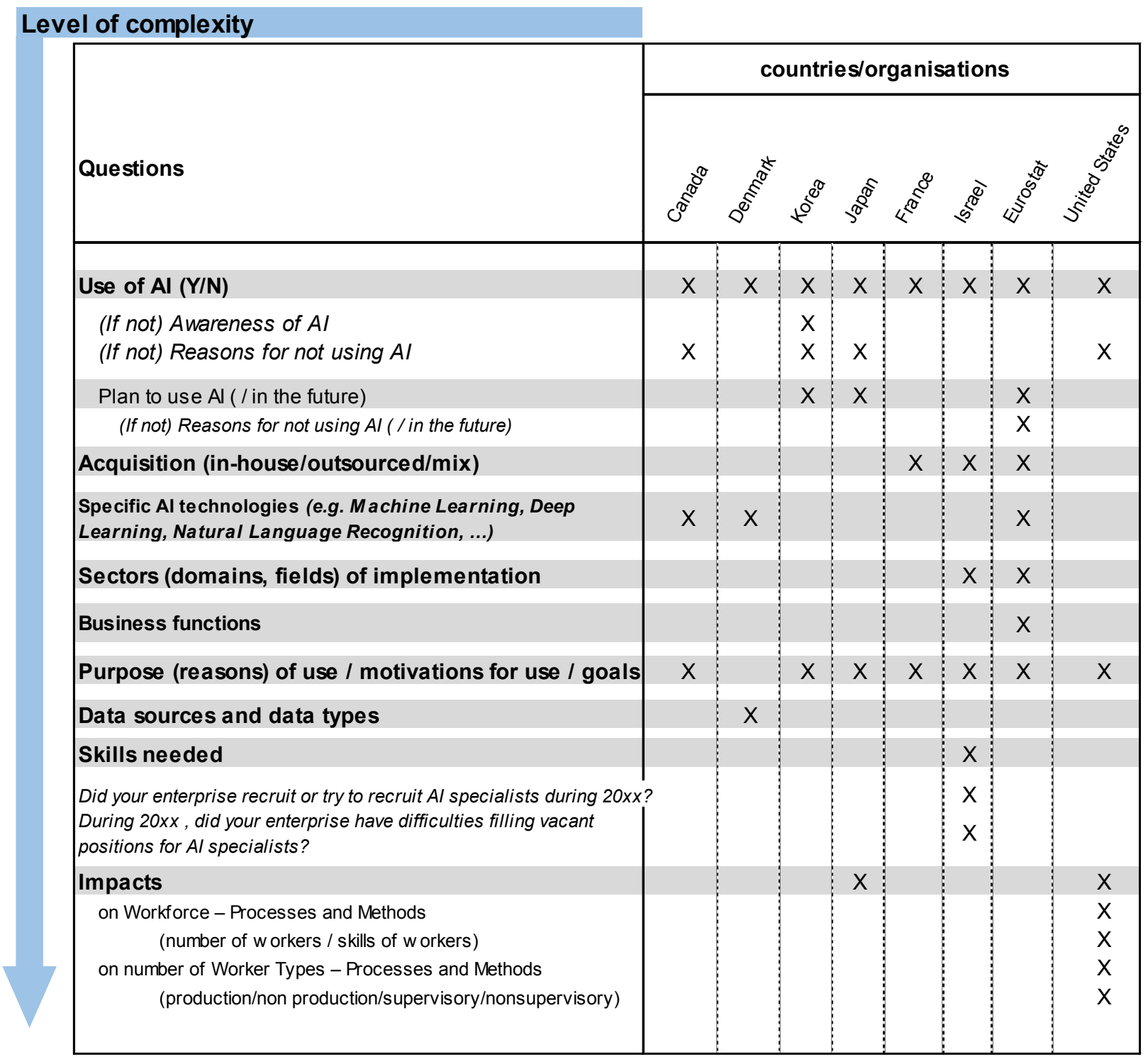

Source: OECD, compiled from various official surveys questionnaires.

Overall, the table shows that the coverage is relatively large for questions that relate to simple or intermediate levels of sophistication: Al use occurrence and Al use purposes, and to a lesser extent, acquisitions, technologies and sectors. At an upper sophistication level of data sources and types, skills, and impacts, the coverage is much narrower. The sections below reviews the questions related to Al included in the available official survey questionnaires.

\section{Al usage or adoption status}

Initially considered as an emerging technology, Artificial Intelligence usage was first mainly surveyed using simple "Yes/ No" question, such as: "In 2017, did this business use any of the following emerging technologies? => Artificial Intelligence" (Statistics Canada, 2018), or "In 2019, did your company use software and equipment incorporating Al technologies?" (INSEE, 2018). In the United States, the first measurement of business technologies did not even mentioned the expression "Artificial Intelligence" but 
rather used elementary -or components of- Al technologies, such as Machine Learning or Natural Language Processing with respective definitions. The question simply asks: "In 2017, to what extent did this business use the following technologies in producing goods or services?" (US Census Bureau, 2018a and 2018b). The second measurement (US Census Bureau, 2019) clearly uses the expression "Artificial Intelligence" and defines it as such (see previous section on Defining $A l$ ) within a more complex approach that includes motivations and impacts (see below).

Longer formulations of $\mathrm{Al}$ adoption questions in the surveys also mirror the status of $\mathrm{Al}$ as an emerging technology. Al is not always fully implemented within the firms. In Japan, questions simply ask for the status of Al introduction, coupled with that of Internet of Things (IOT), as shown in the Table 2.3. In the United States, the questions differentiate between testing and using Al and between various intensity levels of Al use (Table 2.4).

Table 2.3. Al and loT introductory status measurement in Japan, 2017

\section{Question 4: I would like to ask about the introduction and us age status of IoT / AI in your company.}

(1) Does your company introduce systems and services for $\mathrm{IoT}^{1}$ and $\mathrm{AI}^{2}$ respectively?

Please circle one applicable number.

\begin{tabular}{|c|l|c|c|c|}
\hline \multicolumn{2}{|c|}{} & \multicolumn{3}{|c|}{ IoT (collection of digital data via ne twork) } \\
\cline { 3 - 5 } & Introducing & $\begin{array}{l}\text { Not introducing } \\
\text { but considering }\end{array}$ & $\begin{array}{l}\text { Not introduced } \\
\text { and not intended }\end{array}$ \\
\hline \multirow{2}{*}{} & Introducing & 1 & 4 & 7 \\
\cline { 3 - 5 } $\begin{array}{c}\text { AI } \\
\text { (Data } \\
\text { analys is })\end{array}$ & $\begin{array}{l}\text { Not introducing } \\
\text { but considering }\end{array}$ & 2 & 5 & 8 \\
\cline { 3 - 5 } & $\begin{array}{l}\text { Not introduced } \\
\text { and not intended }\end{array}$ & 3 & 6 & 9 \\
\hline
\end{tabular}

Note 1: IoT here refers to various things (information sensors, PCs, smartphones, tablets, etc., sensors, office equipment, home appliances, industrial machinery, crime prevention / disaster prevention equipment, vehicles, etc.) Think of it as being connected to a network such as a LAN and collecting and storing the status as digital data.

Note 2: AI (artificial intelligence) here is used for learning, inference, recognition, and judgment through data analysis.

Please circle the relevant number. For example, "IoT has been introduced " but "AI has not been introduced but is considered", If "Yes", circle "2". 


\section{Table 2.4. Al usage or test measurement question in the United States, 2018}

\section{E.3 Production Technology for Goods and Services}

During the three years 2016 to 2018 , to what extent did this business use the following technologies in production processes for goods or services?

\section{Artificial Intelligence \\ Did not use \\ Tested, but did not use in production or service \\ Low use \\ Moderate use \\ High use \\ Don't know}

Source: US Census Bureau, 2019

\section{Barriers and obstacles to Al adoption}

When surveyed, the reasons for not using Al relate generally to well identified issues: no business needs identified or of interest of management, the lack of knowledge of available technologies, employees lack of skills, costs (of service, equipment or implementation), security or privacy concerns, or legal issues barriers or concerns.

Questions are also specifically addressing issues such as the insufficient communication infrastructure required for the introduction (Japan), the incompatibility with existing equipment and software (Canada), or inadequate results quality (Korea).

The United States approach, when asking about factors that adversely affected the adoption and utilisation of Al technology, address similar issues but also includes the lack of maturity for the technology or the lack of reliability for the required data.

Beyond the status of $\mathrm{Al}$ introduction or adoption, surveys focus more in detail on a broader series of issues related to $\mathrm{Al}$ acquisition and implementation within the firm. They include the ways $\mathrm{Al}$ is acquired by the firm, the various types of $\mathrm{Al}$ technologies or applications, the type of business function involved, the type of data collected and use, the sectors where Al is implemented, the associated skills needed and how to recruit them.

\section{Al acquisition}

Developments of Al systems currently follow different paths until reaching the business as final user. Al systems may have been developed fully in-house (by firm's own employees), may result from commercial systems purchased ready-to-use, or from commercial systems ultimately modified by own employees, or may have been bought from external providers that were contracted to develop them. According to recent research, Al will not be an off-the-shelf product for most of the firms in the near future, due to a strong need to teaming with technology partners (Brock and von Wangenheim, 2019).

As a general-purpose technology, Al is not a single monolithic technology. Al systems implementation occurs through various technologies or applications with Al components. The Table 2.5 below illustrates, with selected examples, how Al use may be broken down according to more detailed technologies associated with various fields (language, text, vision, voice, automation, etc.). 
Table 2.5. Examples of Artificial Intelligence Technologies / field of application surveyed ${ }^{1}$

\begin{tabular}{|c|c|c|}
\hline Canada & Eurostat² & United States ${ }^{3}$ \\
\hline Machine Learning & $\begin{array}{l}\text { Technologies performing analysis of } \\
\text { written language (text mining) }\end{array}$ & Augmented reality \\
\hline $\begin{array}{ll}\text { Natural } & \text { Language } \\
\text { Processing } & \end{array}$ & $\begin{array}{l}\text { Technologies converting spoken } \\
\text { language into machine-readable format } \\
\text { (speech recognition) }\end{array}$ & $\begin{array}{l}\text { Automated guided vehicles (AGV) } \\
\text { or AGV systems }\end{array}$ \\
\hline $\begin{array}{l}\text { Natural Language } \\
\text { generation }\end{array}$ & $\begin{array}{l}\text { Technologies generating written or } \\
\text { spoken language (natural language } \\
\text { generation) }\end{array}$ & $\begin{array}{l}\text { Automated storage and retrieval } \\
\text { systems }\end{array}$ \\
\hline $\begin{array}{l}\text { Virtual Agents (e.g. } \\
\text { animated } \quad \text { Customer } \\
\text { Service } \\
\text { Representatives) }\end{array}$ & $\begin{array}{l}\text { Technologies identifying objects or } \\
\text { persons based on images (image } \\
\text { recognition, image processing) }\end{array}$ & Machine learning \\
\hline $\begin{array}{l}\text { Speech Recognition } \\
\text { (e.g. dictating word) }\end{array}$ & $\begin{array}{l}\text { Machine learning (e.g. deep learning) for } \\
\text { data analysis }\end{array}$ & Machine vision \\
\hline $\begin{array}{l}\text { Harware with integrated } \\
\mathrm{Al}\end{array}$ & $\begin{array}{l}\text { Technologies automating different } \\
\text { workflows or assisting in decision making } \\
\text { (software-based robotic process } \\
\text { automation) }\end{array}$ & Natural language processing \\
\hline Decision Management & $\begin{array}{l}\text { Technologies enabling physical } \\
\text { movement of machines via autonomous } \\
\text { decisions based on observation of } \\
\text { surroundings (autonomous robots, self- } \\
\text { driving vehicles, autonomous drones) }\end{array}$ & $\begin{array}{l}\text { Radio-frequency } \\
\text { (RFID) system }\end{array}$ \\
\hline \multirow[t]{3}{*}{ Other } & & Robotics \\
\hline & & $\begin{array}{l}\text { Touchscreens/kiosks for customer } \\
\text { interface (Examples: self- } \\
\text { checkout, self-check-in, } \\
\text { touchscreen ordering) }\end{array}$ \\
\hline & & Voice recognition software \\
\hline
\end{tabular}

Note: 1 . The table strictly reproduces the order in which the technologies are listed in the questionnaires. Their relative position does not imply a specific relative importance.

2. Eurostat, Community Survey on ICT Usage and E-commerce in Enterprises 2021, version 1.2 final, as of April 2020.

3. For the United States, all technologies listed do not necessarily directly relate to Al.

Source: Compiled from Statistics Canada (2019), Eurostat, and US Census Bureau (2019).

\section{Field of activity}

Business surveys always include questions related to sectors or industry, based on national industrial classifications. ICT use surveys are not exceptions. An additional specific question on the field of activity for Al use is proposed by Israel (CBS, 2019). Items listed include a mix of industrial coverage (e.g. banking, financial services; transport; professional, scientific and technical activities; etc.) and generic business functions (e.g. sales and marketing, manufacturing and industrial production; information and cybersecurity; etc.). A separate question -more focused- on business functions is also proposed (see below).

\section{Purpose of Al use: from business functions to broader economic goals}

Various steps of the business process and associated functions (e.g. sourcing, production, human resources management, financial flows, etc.) are increasingly digitalised, as are similarly growing opportunities to introduce Al systems, components or applications. 
Existing survey questions asking about $\mathrm{Al}$ use purposes distinguish between specific business functions or management fields: marketing, production processes, management and administration, logistics, security, human resources, etc. (Table 2.6).

In the Eurostat survey approach, each of the business functions is provided with several examples of possible Al implementations (not reproduced in the table). For example for marketing or sales: i) chatbots based on natural language processing for customer support or ii) customer profiling, pricing optimization, personalized marketing offers, market analysis based on machine learning; and for logistics: i) autonomous robots for pick-and-pack solutions in warehouses, ii) route optimization based on machine learning, iii) autonomous robots for parcel shipping, tracing, distribution and sorting, etc.

In Israel, the Al use purposes relate to a list of items combining precise defined tasks and specific business functions.

In the United States, the survey look at $\mathrm{Al}$ as one of the selected technologies used in the production process for goods and services (together with Cloud-based computing systems and applications, specialised software and equipment, and robotics). The question on the purpose of use focuses on the production area, and specifically on processes and methods.

\section{Table 2.6. Purpose of Al use: business functions and management fields}

\begin{tabular}{|c|c|c|}
\hline EUROSTAT & Israel & United States \\
\hline $\begin{array}{l}\text { Does your enterprise use } \\
\text { Artificial Intelligence software or } \\
\text { systems for any of the following } \\
\text { purposes? }\end{array}$ & $\begin{array}{l}\text { For what purposes is Al used by } \\
\text { your enterprise? }\end{array}$ & $\begin{array}{l}\text { During the three years } \\
2016 \text { to } 2018 \text {, why did this } \\
\text { business adopt and use Al } \\
?\end{array}$ \\
\hline (Yes / No / Not applicable) & Please select all that apply & Select all that apply \\
\hline $\begin{array}{l}\text { a) Artificial Intelligence software or } \\
\text { systems for marketing or sales } \\
\text { b) Artificial Intelligence software or } \\
\text { systems for production processes } \\
\text { c) Artificial Intelligence software or } \\
\text { systems for organisation of } \\
\text { business administration processes } \\
\text { d) Artificial Intelligence software or } \\
\text { systems for management of } \\
\text { enterprises } \\
\text { e) Artificial Intelligence software or } \\
\text { systems for logistics } \\
\text { f) Artificial Intelligence software or } \\
\text { systems for ICT security } \\
\text { g) Artificial Intelligence software or } \\
\text { systems for human resources } \\
\text { management or recruiting }\end{array}$ & $\begin{array}{l}\text { 1. Automation of processes, } \\
\text { equipment and machinery (including } \\
\text { robotics, vehicles and drones). } \\
\text { 2. Optimization and increasing } \\
\text { effectiveness of resource usage, } \\
\text { production, shipping, handling and } \\
\text { distribution. } \\
\text { 3. Recruiting, managing and } \\
\text { developing human resources. } \\
\text { 4. Optimization of advertising, } \\
\text { marketing and sales. } \\
\text { 5. Prediction, risk management and } \\
\text { assisting in decision-making. } \\
\text { 6. Identifying, managing and } \\
\text { preventing security incidents, fraud } \\
\text { and money laundering. } \\
\text { 7. Quality control and prevention of } \\
\text { deviations and hazards. } \\
\text { 8. Customer service and virtual } \\
\text { service providers. } \\
\text { 9. Development, design and } \\
\text { customization of products. } \\
\text { 10. Taxation, accounting and } \\
\text { compliance with the law and } \\
\text { regulation. } \\
\text { 11. Other }\end{array}$ & $\begin{array}{l}\text { - To automate tasks } \\
\text { performed by labor } \\
\text { - To upgrade outdated } \\
\text { processes and methods } \\
\text { - To improve quality or } \\
\text { reliability of processes } \\
\text { methods } \\
\text { - To expand the range of } \\
\text { goods and services } \\
\text { - To adopt standards and } \\
\text { accreditation } \\
\text { Some other reasons }\end{array}$ \\
\hline
\end{tabular}

Source: Compiled from Eurostat (2020), CBS (2019), and US Census Bureau (2019) 
Alternatively, Al use purposes, as listed in the questions, remain at a level of global economic goals. In that case, they are much less focused and relate classically to productivity, cost, revenue, or customer service (Table 2.7).

Table 2.7. Purpose of Al use: broader economic goals

\begin{tabular}{|c|c|c|}
\hline Canada & Japan & Korea \\
\hline $\begin{array}{l}\text { For which of the following } \\
\text { reasons did this business use } \\
\text { artificial intelligence in 2019? }\end{array}$ & $\begin{array}{l}\text { What is the purpose of } \\
\text { digital data collection and } \\
\text { analysis? }\left(^{*}\right)\end{array}$ & $\begin{array}{l}\text { For what purpose was your } \\
\text { business / organization using Al } \\
\text { technology and service? }\end{array}$ \\
\hline $\begin{array}{l}\text { 1. Develop or increase knowledge } \\
\text { about relations with customers or } \\
\text { clients } \\
\text { 2. Develop a new good or service } \\
\text { 3. Improve an existing good or } \\
\text { service } \\
\text { 4. Develop or improve internal } \\
\text { processes } \\
\text { 5. Other }\end{array}$ & $\begin{array}{l}\text { 1. Efficiency improvement } \\
\text { and business improvement } \\
\text { 2. Business continuity } \\
\text { 3. Overall business } \\
\text { optimization } \\
\text { 4. New business I } \\
\text { management } \\
\text { 5. Improve customer service } \\
\text { 6. Other }\end{array}$ & $\begin{array}{l}\text { 1. Cost cutting } \\
\text { 2. Decision making support } \\
\text { 3. Increase of productivity } \\
\text { 4. Problem solving } \\
\text { 5. Customer reception and service } \\
\text { 6. Creation of new revenue streams } \\
\text { 7. Other }\end{array}$ \\
\hline
\end{tabular}

Note: $\left({ }^{*}\right)$ For firms having answered "1" to the previous question, formulated as follow: "In recent years, it has become possible to create new value and solve problems by collecting or analyzing digital data. Does your company introduce systems and services such as loT and Al to do these things?

1. Introducing/2. Not yet introduced, but will be introduced / 3. Not implemented / 4. I don't know."

Source: Compiled from Canada, Japan and Korea questionnaires

\section{Data sources and data types}

Both the source of data used (e.g. enterprise's own system, public data originating from public authorities, data from Internet), and the types of data used (numerical, text, image or sound), are also among dimensions surveyed (Statistics Denmark, 2019). They contribute to a better understanding of the analytical relevance of the data for the businesses and of how Al inserts in the digital transformation of the firm and its business model.

Canada is also surveying how the businesses are collecting data (Statistics Canada, 2019), but the focus is not specifically Al related. It concentrates rather on customers and clients information (e.g. data collected directly from customers or clients, from data mining, via contracted third party, or via loyalty or reward programs) ${ }^{7}$.

\section{Al Skills needed}

ICT use surveys regularly include questions related to the difficulties to recruit ICT specialists (e.g. Australia in 2017, Canada in 2019, Eurostat since 2014). The same question is included, but narrowed to Al specialists, by Israel (CBS, 2019).

The issue of lack of skills is also one of the answering items in the question relating to reasons for not having used Al (Canada, Korea).

\section{Al Impacts}

Al impacts is a largely debated issue. However, existing official surveys include so far only few questions relating to $\mathrm{Al}$ impacts on the business. For the companies having introduced loT and $\mathrm{Al}$ in 2018 (not distinguishing between both), the Japanese survey asks about any overall perceived effect (ranging from 
"very effective" to "negative"). In the United States, the survey (US Bureau of the Census 2019) asks about effects (increase, decrease, no change) of Al technology adoption on numbers and on skills of workers. For numbers, this relate to global, production and nonproduction workers, supervisory and nonsupervisory workers. For skills this relate to the global skill level of workers, and to the scientific, technological, engineering and mathematical skills of workers.

\section{Survey results raises comparison issues}

Overall results from existing official surveys, provided in the two tables below, show that in all the countries surveyed, $\mathrm{Al}$ is not anymore an emerging technology, especially among large firms. More than five percent of large firms were using Machine Learning in the United States in 2017, and more than one fourth in Denmark in 2019.

When available, data by industry also show that Al use is already significant in some industries. In 2017, results from Canada show that near one firm out of five firms was using $\mathrm{Al}$ in finance and insurance industries, and more than one out of six firms in the Information and cultural industries was using Al. In the United States, Machine Learning is the first or second most used technology among a group of advanced technologies, in industries such as manufacturing, wholesale and retail trade, transportation and storage, and information. In Japan, near one firm out of five in transportation and storage as well as finance and insurance industries, has introduced Al.

Table 2.8. Percentage of businesses using Al technology, recent years

\begin{tabular}{|c|c|c|c|c|c|c|}
\hline firm's size band & $\begin{array}{r}\text { Canada }^{1} \\
2017 \\
20+ \\
\end{array}$ & $\begin{array}{r}\text { Denmark }^{2} \\
2019 \\
10+ \\
\end{array}$ & $\begin{array}{c}\text { France }^{3} \\
2018 \\
10+ \\
\end{array}$ & $\begin{array}{r}J^{J a p a n}{ }^{4} \\
2017 \\
100+ \\
\end{array}$ & $\begin{array}{r}\text { Korea }^{5,7} \\
2017 \\
10+ \\
\end{array}$ & $\begin{array}{r}\text { Korea }^{6,7} \\
2018 \\
10+ \\
\end{array}$ \\
\hline All & 4.0 & 6.0 & 11.4 & 14.1 & 1.5 & 2.1 \\
\hline $10-49$ & & 4.8 & 10.8 & - & 1.5 & 1.6 \\
\hline Small (20-99) & 3.2 & & 11.3 & & & \\
\hline $50-99$ & & 6.7 & 12.3 & & & \\
\hline $100-249$ & & 12.1 & 14.3 & - & & \\
\hline $100-299$ & & & $13.1^{\top}$ & 14.2 & & \\
\hline (Medium) 50-249 & & & 13.1 & - & 1.1 & 3.6 \\
\hline$(100-249)$ & 7.1 & & 14.3 & & & \\
\hline Large $(250+)$ & 10.1 & 23.5 & 20.7 & - & 5.4 & 13.9 \\
\hline $300+$ & & & 23.2 & 13.6 & & \\
\hline
\end{tabular}

Notes: 1. Statistics Canada, SIBS 2017.

2. Statistics Denmark 2019. Refers to ML or Al.

3. INSEE 2019. Preliminary results.

4. Communication Usage Trend Survey.

5. 2018 Yearbook of Information Society Statistics.

6. 2019 Yearbook of Information Society Statistics.

7. The data of Korea are based on the establishment level, not on the firm level.

Source: see notes 
Table 2.9. Business Technology Usage Rates in the United States, 2017 (\%)

\begin{tabular}{lrcr}
\hline Technology & Using & Testing & Using* $^{*}$ \\
\hline Touchscreens & 4.5 & 0.7 & 13.2 \\
Machine Learning & 2.2 & 0.5 & 5.4 \\
Voice Recognition & 2.1 & 0.5 & 5.3 \\
Machine Vision & 1.4 & 0.3 & 3.4 \\
Robotics & 1.0 & 0.2 & 6.8 \\
Natural Language Processing & 1.0 & 0.3 & 3.5 \\
RFID & 0.8 & 0.3 & 5.2 \\
Augmented Reality & 0.7 & 0.3 & 1.3 \\
Automated Guided Vehicles & 0.6 & 0.1 & 1.6 \\
\hline
\end{tabular}

Source: Beede et al. (2020).

\section{Explaining the differences: selected possible reasons}

Results provided in the two tables above highlight significant differences between countries. How to explain them? Differences in the current results may come from various sources. First, the coverage of the surveys, with the target population surveyed (e.g. business units surveyed can be enterprises or establishments), and both in terms of industries and in terms of size. For example, in Korea, the unit surveyed refer to establishment, not to enterprise. And in Japan, firms employing less than 100 employees are not surveyed, which clearly pushes the share of firms using Al upward (see third point below). Second and as previously underlined, the various structures of the questionnaires, the heterogeneity of the Al definitions and the different nature, wordings and scope of questions, may also explain part of the differences between countries. Third, as frequently observed for other emerging technologies, early birds in Al adoption are primarily large firms and firms from the ICT and high tech sectors. In addition, Al is often a part of a firms digital transformation journey and combined or merged with other technologies such as big data analysis, loT and cloud computing. The uptake of those complementary technologies may contribute to explain differences between countries.

The need for international comparability in Al measurement is strong, but the observation simply shows that we are not there yet. 


\section{Examples of non-official Al measures}

Existing official measures are struggling to keep up with the rapid pace of Al. At the same time there is a pressing need to identify and share indicators to show where and how Al is developed, used, by whom, how fast, and in which sectors. To be able to deliver up-to-date policy relevant statistics it is suggested that official statistical information systems will need to build partnerships with businesses and academia.

$\mathrm{Al}$ is a new and emerging area and it takes time for official statistics to incorporate it. Pending inclusion of Al-related in national business surveys in the coming years this section explores a selection of smallerscale non-official measurement efforts with a view to better understand challenges of reliable Al measures. Policy makers may also use non-official AI measures from Academia and consultancy firms such as BCG, PWC and McKinsey.

The section below highlights Al definitions used by different stakeholders. In accordance with the official Al definitions discussed earlier there are two areas that are problematic. The first one is the notion of a system with intelligence, i.e. the ability to think, which is vague. Al researchers use the notion of rationality to describe the term intelligence. It refers to the ability to choose the best action to take in order to achieve a certain goal, given certain criteria to be optimised and the available resources. The second problematic area is the term Al-system. It is difficult to capture as Al-systems usually comprise Al-based components embedded in a larger system, rather than a stand-alone system. Many times Al users in firms may not even know that they are using Al. That is why some Al definitions include examples. The McKinsey definition below lists examples where machines have the ability to perform physical tasks using cognitive functions such as physical robotics, autonomous driving, and manufacturing work.

Below are some examples of Al definitions that guides how the survey questions are designed. It is interesting to note that the definitions are similar to that of the statistical agencies presented in the beginning of the paper. There seems to be a lean towards a common wording when describing what $\mathrm{Al}$ is. Even though the Al definitions show similarities, the survey questions along with the methodology used to calculate the economic value of Al differ between all the surveys in Table 3.1.

PWC (2018)

Broad definition:

"Al is a collective term for computer systems that can sense their environment, think, and in some cases learn, and take action in response to what they're sensing and their objectives. Forms of Al in use today include: digital assistants, deep question and answering, machine vision and many others." 
McKinsey Analytics (2019)

"We define artificial intelligence (Al) as the ability of a machine to perform cognitive functions that we associate with human minds (such as perceiving, reasoning, learning, and problem solving) and to perform physical tasks using cognitive functions (for example, physical robotics, autonomous driving, and manufacturing work)."

In order to measure Al use in firms McKinsey moves beyond the broad definition of what $\mathrm{Al}$ is and focuses on what $\mathrm{Al}$ is in relation to a firms business processes.

"We define Al use in standard business processes as embedded Al in at least one product or business process for at least one function or business unit."

Private Al surveys have merits but are also attached with some drawbacks. A common problem with private Al surveys is often the lack of statistical robustness and a proper sampling frame which calls representation into question. Ideally, the results of Al surveys could be used to guide national Al policy decisions. However, it is difficult to make generalisations from private Al surveys because the types of firms included are typically not selected randomly from a target population and the response rate of the surveys are often unknown or low. In many cases the data is not open to other researchers whereby the results cannot be replicated.

In addition, the steps from Al definition to survey question to the results generated are somewhat illusive in the measures described in Table 3.1. In contrast with official Al measures, consultancy firms seldom provide detailed information on the questions asked in the surveys. To some extent, consultancy firms also base their Al measures on so called Al use cases. Examples described in Table 3.1 are McKinsey (2019); PWC $(2017,2018)$. An Al use case comprise knowledge of a customer that has bought the consultancy firms Al services. McKinsey, for example, draws on their Al use cases to estimate the benefits of Al use in the Swedish public sector. Results show that the Al benefits were estimated at 140 billion SEK (DIGG, 2019). It is argued that the Al impact generated by one customer is context independent and can be used to calculate benefits in organisation in general worldwide (e.g. organisations in the same sector). Spillman (2014) however, highlight that studying particular cases to produce generalisations that can be applied to other situations are common in statistical generalisations e.g. from sample to population but more disputed in qualitative case studies. To what extent knowledge from an Al use case in one firm is context independent and can be generalised to other organisations is an interesting question. 
Table 3.1. Examples of non-official Al measures

\begin{tabular}{|c|c|c|c|c|}
\hline Organisation & Name of report & Focus & Results & Caveat \\
\hline PWC (2017) & Sizing the Prize & $\begin{array}{l}\text { Global economic } \\
\text { impact using an Al } \\
\text { impact index } \\
\text { measuring the } \\
\text { value potential } \\
\text { based } \\
\text { assumptions } \\
\text { generated from } 300 \\
\text { Al use cases. }\end{array}$ & $\begin{array}{l}\text { GDP could be up } 14 \% \\
\text { in } 2030 \text { as a result of } \\
\mathrm{Al} \text {, sectors with the } \\
\text { biggest gains are } \\
\text { retail, financial } \\
\text { services and } \\
\text { healthcare as } \mathrm{Al} \text { is } \\
\text { expected to increase } \\
\text { productivity, product } \\
\text { quality and } \\
\text { consumption. }\end{array}$ & $\begin{array}{l}\text { Origin of } 300 \text { use } \\
\text { cases not clearly } \\
\text { defined. } \\
\text { Al systems also } \\
\text { cover systems that } \\
\text { are not intelligent. }\end{array}$ \\
\hline PWC (2018) & $\begin{array}{l}\text { The } \\
\text { Macroeconomic } \\
\text { Impact of Artificial } \\
\text { Intelligence }\end{array}$ & $\begin{array}{l}\text { More in depth } \\
\text { global economic } \\
\text { impact measure. }\end{array}$ & & $\begin{array}{l}\text { The same caveat as } \\
\text { the } 2017 \text { report. }\end{array}$ \\
\hline MGI (2017) & $\begin{array}{l}\text { A future that } \\
\text { works }\end{array}$ & $\begin{array}{l}\text { Automation which } \\
\text { encompasses Al- } \\
\text { driven automation. }\end{array}$ & $\begin{array}{l}\text { Almost } 50 \% \text { of the } \\
\text { work people do today } \\
\text { have the potential to } \\
\text { be automated by } \\
\text { adapting currently } \\
\text { demonstrated } \\
\text { technology. }\end{array}$ & $\begin{array}{l}\text { Captures } \\
\text { automation but the } \\
\text { extent to which } \mathrm{Al} \text { is } \\
\text { covered is unclear. }\end{array}$ \\
\hline $\begin{array}{l}\text { McKinsey } \\
(2019)\end{array}$ & $\begin{array}{l}\text { Global Al Survey: } \\
\text { Al proves its } \\
\text { worth, but few } \\
\text { scale impact }\end{array}$ & $\begin{array}{l}\text { Dissemination and } \\
\text { benefits from Al use } \\
\text { in firms. }\end{array}$ & $\begin{array}{l}58 \% \text { have embedded } \\
\text { at least one of nine Al } \\
\text { capabilities into a } \\
\text { process or product in } \\
\text { at least one function or } \\
\text { business unit. }\end{array}$ & $\begin{array}{l}\text { The degree of } \\
\text { coverage by the } \\
\text { population is not } \\
\text { clearly defined but it } \\
\text { is likely that } \\
\text { surveyed firms are } \\
\text { McKinsey } \\
\text { customers. }\end{array}$ \\
\hline $\begin{array}{l}\text { Ransbotham } \\
\text { et al. (2019) }\end{array}$ & Winning with $\mathrm{Al}$ & Al success factors. & $\begin{array}{l}40 \% \text { of firms making } \\
\text { significant } \\
\text { investments in } \mathrm{Al} \text { do } \\
\text { not report business } \\
\text { gains from Al. }\end{array}$ & $\begin{array}{l}\text { The degree of } \\
\text { coverage by the } \\
\text { population is } \\
\text { somewhat unclear } \\
\text { whereby } \\
\text { generalisations are } \\
\text { difficult. }\end{array}$ \\
\hline
\end{tabular}

Source: OECD

From an economic lens, it would be valuable to able to separate the Al-driven automation from general automation and know to what extent an Al component is embedded in robots. However, studies such as the MGI (2017) presented in the table above provide little information on the extent of Al-driven automation or the number of robots that actually use any means of Al. Still, it is argued that these type of studies still provide information on installed infrastructure susceptible to adopting new Al technologies.

To sum up capturing $\mathrm{Al}$ is complex as many surveys can be perceived as measuring activities where $\mathrm{Al}$ may or may not be part of a business operation or a product. In some measures, the Al component may be embedded to the extent that is almost inaccessible and impossible to disentangle, thus difficult to capture in survey. 


\section{Matching policy and Al measures}

Given the potential benefits and the challenges policy makers need updated knowledge to develop, implement and improve Al policies. To do so, it is important to showcase Al measures to allow countries to compare policy responses and to monitor progress in order to develop best practices.

Many countries have launched national Al strategies. It could be argued that effective implementation of these policies, to some extent, depends on reliable measures to monitor Al use in firms. Matching policy goals in national Al strategies to relevant Al measures may include indicators on Al use in firms.

The goal of the German government, for example, is to achieve global excellent in research, development as well as application (i.e. Al use). The German Al strategy reads as follows ${ }^{8}$ :

"The Federal Government is committed to achieving and maintaining leading global excellence in the research, development and application of Al in Germany and Europe."

Bridging the valley of death i.e. closing the gap between university research on $\mathrm{Al}$ and its commercial use in firms is important to deliver economic growth and competitiveness. Whereby, the Al use measures discussed in this paper could be used to monitor some aspects of Al policy implementation when the policy goals cover aspects related to economic growth and competitiveness.

Still, there are important Al policy goals that are more complicated to match with relevant Al measures. The recent launch of the OECD AI Observatory aim to provide policy makers with AI measures to monitor the responsible development of trustworthy Al systems for the benefit of society, as embodied by the OECD Al Principles adopted in May 2019 (see annex b). Matching the Al principles to the official measures is difficult as the principles cover many aspects that are not yet measured in official statistics. Still, an initial attempt is made to match ONE Al principles ${ }^{9}$ to the measures presented in this paper. It could be argued that the Al principles cover many facets and therefore requires a mixture of indicators to measure policy progress. The official measures presented in the paper could be used as proxy in an indicator mix that focuses the first Al principle - "Al should benefit people and the planet by driving inclusive growth, sustainable development and well-being". The current measures focuses on Al use in firms, which could, in turn, contribute to sustainable economic growth for nations.

There is also a possibility that upcoming official surveys could be widened to include indicators that better match the OECD Al principles. One such example could be new measures on Al security and risk which could service as proxies in an indicator mix that focuses on the forth Al principle - "Al systems must function in a robust, secure and safe way throughout their life cycles and potential risks should be continually assessed and managed". Finally, it is important to highlight that the OECD AI principles are created to develop trustworthy Al that benefits society whereby official Al measures may need to be even better aligned with current and future Al policy needs. 


\section{Conclusions and next steps}

Al is transforming businesses and offers both possibilities and challenges. Finding the right balance between the two is not an easy task and further knowledge is required to capture all the nuances. This paper can help identify possibilities that can arise when firms use Al. In Al policy the possibilities are often described in terms of economic growth and competitiveness. In order for Al to contribute to growth and competitiveness firms have to use $\mathrm{Al}$ in their day-to-day operation. That is one reason why policy makers need measures that can answer the question: To what extent do firms use $\mathrm{Al}$ in their business? To understand what action to take, policy makers also need detailed knowledge of which firms use Al i.e. this paper highlights the finding that larger firms are soaring ahead of smaller firms.

Still, it is difficult to measure Al until there is a clear statistical definition of what to measure. That is why this paper offers a novel cross-country analysis of measures on Al use in firms and focuses mainly on statistically sound official statistics. It provides an overview of existing statistical definitions and Al survey questions and hints towards the need for continuous renewal. Al is developing in a rapid pace, which means that it will continue to be somewhat of a moving measurement target. This paper takes stock of the Al use measures available today and initiates a discussion of what we should be collecting in order to inform present and future Al policy.

The results in this paper indicate that:

- A text analysis of $\mathrm{Al}$ measurement definitions in 7 countries and 2 international organisations highlights that they cover similar topics but in slightly different ways

- However, the issues raised by differences in the definition of $\mathrm{Al}$ are compounded by differences in the design, scope and coverage of the surveys across countries

- Al policy objectives are much broader than what is currently measured in Al surveys, which makes it hard to monitor and evaluate policy in this field.

Official Al use measures also deliver micro data that, on national level, can be linked to business register data such as productivity, value added and profitability. Connecting Al use in firms to productivity and profitability is high on the policy agenda.

Al does not only bring possibilities but also challenges as highlighted in the OECD Al principles e.g. ensuring secure, trustworthy and transparent Al. Areas that, to our knowledge, is currently not visible in official statistics.

\section{Next steps}

Measuring $\mathrm{Al}$ is as complex as the $\mathrm{Al}$ is typically bundled with other technologies. $\mathrm{Al}$ is often not a standalone system but part of a larger system. Sometimes it may be embedded to the extent that is becomes invisible. Yet, sound and comparable measures are essential to measure the progress of national Al strategies among countries.

Possible avenues for future work include: 
- Develop a clear Al measurement agenda, i.e. agreed definitions and methodologies, that enables international comparison - especially measures on Al diffusion in firms;

- Build a repository of statistically rigorous questions on Al use in firms, in order to showcase quality Al indicators suitable to inform policy.

The AI ONE Group of Experts is currently developing a user-friendly framework to classify and help policy makers to better understand Al systems and the different policy considerations associated with each type of $\mathrm{Al}$ systems. This will also contribute to the measurement agenda of $\mathrm{Al}$ developments associated with the Framework's dimensions to inform policy.

MADE could continue working towards the above objectives and contribute to the OECD Al Policy Observatory in the Programme of Work and Budget PWB 2021-22. 


\section{References}

Acemoglu, D., \& Restrepo, P. (2018). Artificial Intelligence, Automation and Work. MIT working paper.

Agrawal, A., Gans, J., \& Goldfarb, A. (2019). The Economics of Artificial Intelligence: An Agenda: University of Chicago Press.

Beede, D., Brynjolfsson, E., Buffington, C., Dinlersoz, E., Foster, L., Goldschlag, N., . . Zolas, N. (2020). Measuring Technology Adoption in Enterprise-Level Surveys: The Annual Business Survey Paper presented at the ASSA 2020.

Brock, J. K.-U., \& von Wangenheim, F. (2019). Demystifying AI: What Digital Transformation Leaders Can Teach You about Realistic Artificial Intelligence. California Management Review, 61(4), 110-134. doi:10.1177/1536504219865226

Brynjolfsson, E., Rock, D., \& Syverson, C. (2017). Artificial Intelligence and the Modern Productivity Paradox: A Clash of Expectations and Statistics. NBER.

DIGG. (2019). Promote the public sectors' ability to use AI. Retrieved from

EC. (2019). A DEFINITION OF AI: MAIN CAPABILITIES AND DISCIPLINES. Retrieved from Garbuio, M., \& Lin, N. (2019). Artificial Intelligence as a Growth Engine for Health Care Startups: EMERGING BUSINESS MODELS. California Management Review, 61(2), 59-83. doi:10.1177/0008125618811931

Haenlein, M., \& Kaplan, A. (2019). A Brief History of Artificial Intelligence: On the Past, Present, and Future of Artificial Intelligence. California Management Review, 61(4), 514. doi:10.1177/0008125619864925

Le Cun, Y. (2020, 7 février 2020). Les applications bénéfiques de l'intelligence artificielle vont, de loin, l'emporter. Le Monde.

McKinsey. (2019). Global AI Survey: AI proves its worth, but few scale impact. Retrieved from McKinsey \& Company:

MGI. (2017). A Future That Works: Automation, Employment, and Productivity. Retrieved from OECD. (2019a). Artificial Intelligence in Society. Paris.

OECD. (2019b). Proposal for the OECD AI Policy Observatory. Retrieved from

PWC. (2017). Sizing the prize: What's the real value of AI for your business and how can you capitalise? Retrieved from

PWC. (2018). The macroeconomic impact of artificial intelligence. Retrieved from

Ransbotham, S., Shervin, K., Fehling, R., LaFountain, B., \& Kiron, D. (2019). Winning With AI. Retrieved from MIT Sloan Management Review and Boston Consulting Group:

Spillman, L. (2014). Mixed Methods and the Logic of Qualitative Inference. Qualitative Sociology, 37(2), 189-205. doi:10.1007/s11133-014-9273-0 


\section{Annex A. Questionnaires}

\section{EUROSTAT}

\section{EUROSTAT, Community Survey on ICT Usage and E-commerce in Enterprises 2021, version 1.2, final.}

\section{Module F: Artificial Intelligence}

(Scope: enterprises with access to the internet, i.e. if $A 1>0$ )

Artificial intelligence refers to systems that use technologies such as: text mining, computer vision, speech recognition, natural language generation, machine learning, deep learning to gather and/or use data to predict, recommend or decide, with varying levels of autonomy, the best action to achieve specific goals.

Artificial intelligence systems can be purely software based, e.g.:

- chatbots and business virtual assistants based on natural language processing,

- face recognition systems based on computer vision or speech recognition systems,

- machine translation software,

- data analysis based on machine learning, etc.

or embedded in devices, e.g.:

- $\quad$ autonomous robots for warehouse automation or production assembly works

- autonomous drones for production surveillance or parcel handling, etc.

F1. Does your enterprise use any of the following Artificial Intelligence technologies?

a) Technologies performing analysis of written language (text mining)

b) Technologies converting spoken language into machine-readable format (speech recognition)

c) Technologies generating written or spoken language (natural language generation)

d) Technologies identifying objects or persons based on images (image recognition, image processing)

e) Machine learning (e.g. deep learning) for data analysis

f) Technologies automating different workflows or assisting in decision making (Artificial Intelligence based software robotic process automation)

g) Technologies enabling physical movement of machines via autonomous decisions based on observation of surroundings (autonomous robots, self-driving vehicles, autonomous drones) 
If F1 a) to g) = "No" then go to F4 (if optional included) else go to X1

\begin{tabular}{|c|c|c|c|}
\hline \multirow[t]{8}{*}{ F2. } & $\begin{array}{l}\text { Does your enterprise use Artificial Intelligence software or systems for any } \\
\text { of the following purposes? }\end{array}$ & Yes & No \\
\hline & $\begin{array}{l}\text { a) for marketing or sales } \\
\text { e.g. } \\
\text { - chatbots based on natural language processing for customer support, } \\
\text { - customer profiling, price optimisation, personalised marketing offers, market } \\
\text { analysis based on machine learning, etc. }\end{array}$ & $\square$ & $\square$ \\
\hline & $\begin{array}{l}\text { b) for production processes } \\
\text { e.g. } \\
\text { - predictive maintenance based on machine learning, } \\
\text { - tools to classify products or find defects in products based on computer } \\
\text { vision, } \\
\text { - autonomous drones for production surveillance, security or inspection tasks, } \\
\text { - assembly works performed by autonomous robots, etc. }\end{array}$ & $\square$ & $\square$ \\
\hline & $\begin{array}{l}\text { c) for organisation of business administration processes } \\
\text { e.g. } \\
\text { - business virtual assistants based on machine learning and/or natural } \\
\text { language processing, } \\
\text { - voice to text conversion based on speech recognition for document drafting, } \\
\text { - automated planning or scheduling based on machine learning, } \\
\text { - machine translation, etc. }\end{array}$ & $\square$ & $\square$ \\
\hline & $\begin{array}{l}\text { d) for management of enterprises } \\
\text { e.g. } \\
\text { - machine learning to analyse data and help make investment or other } \\
\text { decisions, } \\
\text { - sales or business forecasting based on machine learning, } \\
\text { - risk assessment based on machine learning, etc. }\end{array}$ & $\square$ & $\square$ \\
\hline & $\begin{array}{l}\text { e) for logistics } \\
\text { e.g. } \\
\text { - autonomous robots for pick-and-pack solutions in warehouses, } \\
\text { - route optimization based on machine learning, } \\
\text { - autonomous robots for parcel shipping, tracing, distribution and sorting, } \\
\text { - autonomous drones for parcel delivery, etc. }\end{array}$ & $\square$ & $\square$ \\
\hline & $\begin{array}{l}\text { f) for ICT security } \\
\text { e.g. } \\
\text { - face recognition based on computer vision for authentication of ICT users, } \\
\text { - detection and prevention of cyber-attacks based on machine learning, etc. }\end{array}$ & $\square$ & $\square$ \\
\hline & $\begin{array}{l}\text { g) for human resources management or recruiting } \\
\text { e.g. } \\
\text { - candidates pre-selection screening, automation of recruiting based on } \\
\text { machine learning, } \\
\text { - employee profiling or performance analysis based on machine learning, } \\
\text { - chatbots based on natural language processing for recruiting or supporting } \\
\text { human resources management, etc. }\end{array}$ & $\square$ & $\square$ \\
\hline
\end{tabular}




\begin{tabular}{|l|l|c|c|}
\hline \multirow{2}{*}{ F3. } & $\begin{array}{l}\text { How did you enterprise acquire the Artificial Intelligence software or } \\
\text { systems that it uses? } \\
\text { - Optional }\end{array}$ & Yes & No \\
\hline $\begin{array}{l}\text { a) They were developed by own employees (including those employed in parent } \\
\text { or affiliate enterprise) }\end{array}$ & $\square$ \\
\hline $\begin{array}{l}\text { b) Commercial software or systems were modified by own employees (including } \\
\text { those employed in parent or affiliate enterprise) }\end{array}$ & $\square$ \\
\hline $\begin{array}{l}\text { c) Open-source software or systems were modified by own employees (including } \\
\text { those employed in parent or affiliate enterprise) }\end{array}$ & $\square$ & $\square$ \\
\hline & $\begin{array}{l}\text { d) Commercial software or systems ready to use were purchased (including } \\
\text { examples where it was already incorporated in a purchased item or system) }\end{array}$ & $\square$ & $\square$ \\
\hline
\end{tabular}

Questions F4 and F5 are presented only to respondents who answered 'No' to F1a)-g) i.e. enterprises that did not use any of the Artificial Intelligence technologies listed in question F1.

\begin{tabular}{|c|c|c|c|}
\hline F4. & $\begin{array}{l}\text { Has your enterprise ever considered using any of the Artificial Intelligence } \\
\text { technologies listed in question F1? - Optional } \\
\text { (Filter question) }\end{array}$ & Yes $\square$ & $\begin{aligned} & \text { No } \square \\
-> & \text { go to } X 1\end{aligned}$ \\
\hline \multirow[t]{9}{*}{ F5. } & $\begin{array}{l}\text { What are the reasons for your enterprise not to use any of the Artificial } \\
\text { Intelligence technologies listed in question F1? - Optional }\end{array}$ & Yes & No \\
\hline & a) The costs seem too high & $\square$ & $\square$ \\
\hline & b) There is a lack of relevant expertise in the enterprise & $\square$ & $\square$ \\
\hline & c) Incompatibility with existing equipment, software or systems & $\square$ & $\square$ \\
\hline & d) Difficulties with availability or quality of the necessary data & $\square$ & $\square$ \\
\hline & e) Concerns regarding violation of data protection and privacy & $\square$ & $\square$ \\
\hline & $\begin{array}{l}\text { f) Lack of clarity about the legal consequences (e.g. liability in case of damage } \\
\text { caused by the use of Artificial Intelligence) }\end{array}$ & $\square$ & $\square$ \\
\hline & g) Ethical considerations & $\square$ & $\square$ \\
\hline & h) Artificial Intelligence technologies are not useful for the enterprise & $\square$ & $\square$ \\
\hline
\end{tabular}

Source: Eurostat, Community Survey on ICT Usage and E-commerce in Enterprises, 2021, v. 1.2, Final, April 2020. 


\title{
Canada
}

\section{Statistics Canada, Survey of Innovation and Business Strategy (SIBS) 2017}

\begin{abstract}
Advanced technology use
Technology is broadly defined to include the technical means and know-how required for the production of products. It takes the form of equipment, materials, processes, blue prints and knowledge. Advanced technologies are new technologies (equipment and software) that perform a new function or improve some function significantly better than commonly used technologies in the industry or by competitors.
\end{abstract}

In 2017, did this business use any of the following types of advanced or emerging technologies? Y/N In 2017 refers to the calendar year, January 1 to December 31, 2017.

\section{Advanced technologies}

a. Material handling, supply chain or logistics technologies . . . . . . . . . . . . . . . . C390001

b. Design or information control technologies . . . . . . . . . . . . . . . . . . . . C390002

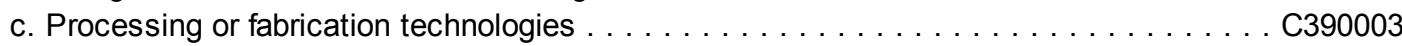

d. Clean technologies

Note: Clean technology refers to any goods or services that reduce environmental impacts through environmental protection activities or through the substantial use of natural resources. . . . . . . . . . . . . . . . . . . . . . . . . . . . . . . . . . . . C390004

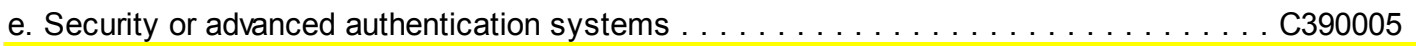

f. Business intelligence technologies
e.g., cloud-based computing systems and big data analytic tools . . . . . . . . . . . C390006

g. Other types of advanced technologies . . . . . . . . . . . . . . . .

\section{Emerging technologies}

h. Nanotechnology . . . . . . . . . . . . . . . . . . . . . . . . . . . . C390008

i. Biotechnology . . . . . . . . . . . . . . . . . . . . . . . . . . . . . . . C390009

j. Geomatics or geospatial technologies . . . . . . . . . . . . . . . . . . . . . . . C390010

k. Artificial intelligence $(\mathrm{Al}) \ldots \ldots \ldots \ldots \ldots \ldots$. . . . . . . . . . . . . . . C390011

I. Integrated Internet of Things (loT) systems

Include systems where devices and objects have communication connectivity. . . . . . . . C390012

m. Blockchain technologies

e.g., crypto-currency, distributed ledgers, secure value exchange protocols, smart contracts . . C 390013

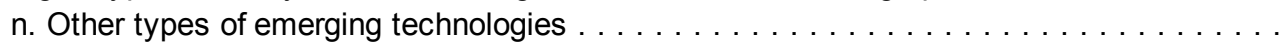

Source: Questionnaire from the Survey of Innovation and Business Strategy (SIBS) 2017. Available at: http://www.statcan.gc.ca/eng/statistical-programs/instrument/5171 Q1 V3-eng.pdf

\section{Statistics Canada, Survey of Digital Technology and Internet Use - 2019}

\section{Use of information and communication technologies (ICTs)}

Use of information and communication technologies (ICTs) - Question identifier:31

\section{Which of the following Information and Communication Technologies (ICTs) did this} business use in $2019 ?$

Information and Communication Technologies (ICTs) consist of the hardware, software, networks and media for the collection, storage, processing, transmission and presentation of information (voice, data, text, images), as well as related services.

Select all that apply.

1: Company-wide computer networks

2: Industry-specific software 
3: Software not specific to this business's industry

4: Customer Relationship Management (CRM) software

5: Electronic Data Interchange (EDI) on the Internet

6: Enterprise Resource Planning (ERP) software

7: Radio Frequency Identification (RFID) tags

8: Cloud computing

9: Internet-connected smart devices, or Internet of Things (IoT)

10: Software and hardware using artificial intelligence (AI)

11: Advanced robotics

12: Big data analytics

13: 3D printing

14: Blockchain technologies

15: Open source software

: OR

16: None

\section{Artificial intelligence (Al)}

Artificial Intelligence $(\mathrm{Al})$ refers to systems that display intelligent behaviour by analyzing their environment and taking actions - with some degree autonomy - to achieve specific goals. Al-based systems can be purely software-based or embedded in a device.

Artificial intelligence (AI) - Question identifier:43

In 2019, which of the following artificial intelligence technologies did this business use?

Exclude the use of search engines and personal virtual assistants.

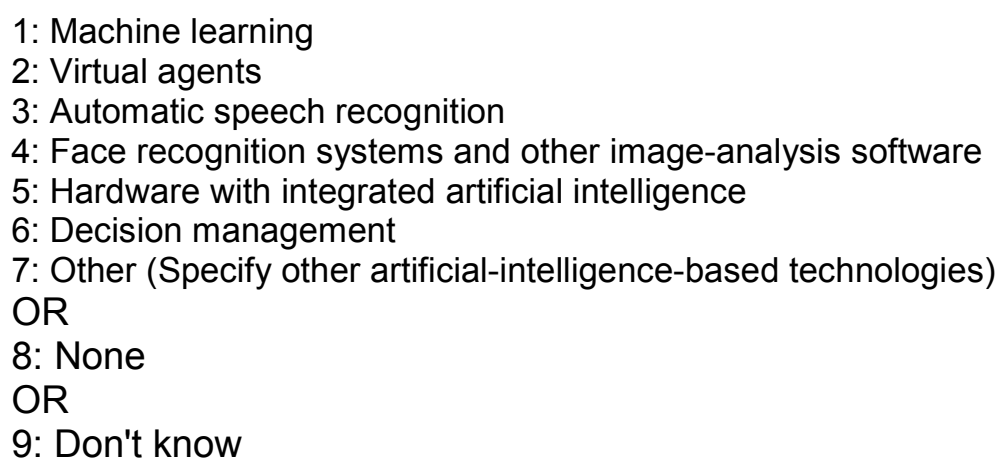

Artificial intelligence (Al) - Question identifier:44

For which of the following reasons did this business use artificial intelligence in 2019?

Exclude the use of search engines and personal virtual assistants.

Select all that apply.

1: Develop or increase knowledge about relations with customers or clients

2: Develop a new good or service

3: Improve an existing good or service

4: Develop or improve internal processes

5: Other

Artificial intelligence (AI) - Question identifier:45

For which of the following reasons did this business not use software or equipment incorporating artificial intelligence technologies in 2019?

Artificial intelligence $(\mathrm{Al})$ refers to systems that display intelligent behaviour by analyzing their environment and taking actions - with some degree autonomy - to achieve specific goals. Al-based systems can be purely software-based or 
embedded in a device.

Select all that apply.

1: Lack knowledge of available technologies

2: No business needs identified

3: Cost of service or equipment

4: Employees lack the skills, training or experience

5: Security or privacy concerns

6: Incompatibility with existing equipment or software

7: Legal issues, barriers or concerns

8: Other

Source: Questionnaire from the Survey of Digital Technology and Internet Use - 2019, Statistics Canada.

Available at:

https://www23.statcan.gc.ca/imdb/p3Instr.pl?Function=assemblelnstr\&lang=en\&ltem Id=12507 $\underline{55}$

\section{Denmark}

\section{Statistics Denmark ICT Usage and E-commerce in Enterprises 2019}

\begin{tabular}{|l|l|}
\hline Al & Use of machine learning and artificial intelligence \\
\hline & $\begin{array}{l}\text { Machine learning and artificial intelligence includes the use of computer software, which with a starting } \\
\text { point in data "thinks", analyzes, problem solves and forms connections in patterns, for instance } \\
\text { images, audio and text. It may include computer generated annual report, chat bots or automated } \\
\text { marketing. }\end{array}$ \\
\hline ERST_Al1 & $\begin{array}{l}\text { Does your enterprise use machine learning or artificial intelligence? } \\
\text { Including services that include this, provided by external suppliers. }\end{array}$ \\
\hline ERST_Al2 & $\begin{array}{l}\text { Does your enterprise use the following data sources for machine learning or artificial } \\
\text { intelligence? }\end{array}$ \\
\hline ERST_AI2a & $\begin{array}{l}\text { a) Data from your enterprise's own systems. } \\
\text { E.g. sensor data from the enterprise's machines, data for customer behavior and accounting data. }\end{array}$ \\
\hline ERST_AI2b & $\begin{array}{l}\text { b) Public data. } \\
\text { E.g. data from public authorities on geographical features, weather, enterprises, income, place of } \\
\text { residence, etc. }\end{array}$ \\
\hline ERST_AI2c & $\begin{array}{l}\text { c) Data from the Internet. } \\
\text { E.g. data from social media like Google+, Twitter, and Facebook. }\end{array}$ \\
\hline ERST_AI3 & $\begin{array}{l}\text { Does the enterprise use the following types of data for machine learning or artificial } \\
\text { intelligence? }\end{array}$ \\
\hline ERST_AI3a & a) Numerical data \\
\hline ERST_AI3b & b) Text data \\
\hline ERST_AI3c & c) Image data \\
\hline ERST_AI3d & d) Sound data \\
\hline SOLICEStatistics Denmark.
\end{tabular}

Source: Statistics Denmark.

\section{France}

\section{INSEE, ICT Usage and E-commerce in Enterprises 2019}

\section{Al module}

Artificial intelligence includes all the technologies aiming at computerization of cognitive tasks traditionally performed by humans: voice recognition, biometrics, image recognition, decision support, etc. 
1. In 2018, did your company use software and / or equipment incorporating artificial intelligence technologies?

- This software and/or equipment has been developed, mainly by employees of your company (including those from the parent company or subsidiaries) $\mathrm{Y} / \mathrm{N}$

- This software and/or equipment has been developed, mainly by an external service provider, to answer specifically the needs of your company $\quad \mathrm{Y} / \mathrm{N}$

- This software and/or this equipment is part of "off-the-shelf" offers from suppliers $\mathrm{Y} / \mathrm{N}$

If "Yes" to at least one item in question 1, go on with question 2

2. In 2018, did your company use software and / or equipment incorporating artificial intelligence technologies to:

- Develop or improve knowledge about or relations with customers? Y/N

- Develop or improve goods or services? Y/N

- Develop or improve internal processes? Y/N

Source: Questionnaire and preliminary 2019 results provided by INSEE. From Survey on information and communication technologies in business 2019, Business ICT 2019, INSEE.

Available at : https://www.insee.fr/fr/metadonnees/source/fichier/TIC2019 questionnaire.pdf

\section{Israel}

Artificial intelligence is that activity devoted to making machines intelligent, and intelligence is that quality that enables an entity to function appropriately and with foresight in its environment.

\section{Does your enterprise use Al technologies and/or services?}

In which fields of activity does your enterprise use Al in?

Please select all that apply

Banking, financial services

Healthcare and wellbeing

Transportation

Information and cyber security

Sales and marketing

Manufacturing and industrial production

Professional, scientific and technical activities

Education

Communication and media

\section{For what purposes is Al used by your enterprise?}

Please select all that apply

Automation of processes, equipment and machinery (including robotics, vehicles and drones).

Optimization and increasing effectiveness of resource usage, production, shipping, handling and distribution.

Recruiting, managing and developing human resources.

Optimization of advertising, marketing and sales.

Prediction, risk management and assisting in decision making.

Identifying, managing and preventing security incidents, fraud and money laundering.

Quality control and prevention of deviations and hazards.

Customer service and virtual service providers.

Development, design and customization of products.

Taxation, accounting and compliance with the law and regulation.

Other 
Did your enterprise recruit or try to recruit Al specialists during 2019?

During 2019 , did your enterprise have difficulties filling vacant positions for Al specialists?

Please select all that apply

The recruitment process lasted longer than 6 months.

The job is vacant for over 6 months and has not yet been filled.

Bureaucratic difficulties in hiring a foreign worker.

Other difficulties.

Who developed the Al systems in your enterprise?

Enterprises own employees (incl. those employed in parent or affiliate enterprises). Y/N

External suppliers, in a way that specifically meets the needs of your business. $\mathrm{Y} / \mathrm{N}$

External suppliers, as part of pre packaged software. Y/N

Source: Central Bureau of Statistics Israel.

\section{$\underline{\text { Japan }}$}

\section{Communication Usage Trend Survey, Part devoted to Businesses, 2017 and 2018.}

The questionnaires 2017 and 2018 are only available in Japanese.

For the Questionniare 2017, the question 4 ask about the introduction and use of loT / Al in the business.

Statistical results for the year 2017 were provided directly to OECD by the Ministry of Internal Affairs and Communications (MIC). The Table xx in the main part of the document is a Secretariat ad-hoc translation of the 2017 Questionnaire Question 4, corresponding exactly to the structure of the original document in Japanese.

Communication Usage Trend Survey 2017 results and questionnaire are available at: https://www.soumu.go.jp/johotsusintokei/statistics/pdf/HR201700 002.pdf 


\section{Korea}

\section{Survey on the Information Society, 2017 and $2018^{10}$}

\section{ARTIFICIAL INTELLIGENCE}

Artificial Intelligence(AI.): AI refers to 'intelligence created by machines', and is implemented by using computer technology to mimic human's ability of learning, inference, perception, and understanding of natural language

Al personal assistant service that provides needed information through voice conversation(SVoice and Bixby of Samsung Electronics, Q-Voice of LG, Siri of Apple, Now of Google, Cortana of Microsoft, Alexa and Echo of Amazon, Al speaker Nugu of SK telecommunications, etc.)

- Robo-advisor that recommends stocks, investment and financial product, credit assessment and evaluation based on Al

- AI go program(AlphaGo of Google), AI system that answers to questions asked in natural language(Watson medical advice of IBM)

Al robot(costumer reception, military use, disaster relief, distribution and transportation, housekeeping robot, robot pets, robot guards, etc.)

- Automation of translation/law/writing articles based on $\mathrm{AI}$

- Driver assistance systems(mobile sensor, automatic parking, emergency braking, drowsy driving prevention, etc.), autonomous car, etc.

(For all respondents)

Did your businesses/organization use Artificial Intelligence technology and service as of Dec.31, 2017?

\begin{tabular}{l|c}
\multicolumn{1}{c|}{ Use } & Mark \\
\hline 1) Yes & $\square$ \\
\hline 2) No, but I know about A.I. & $\square$ \\
\hline 3) No, I don't know about A.I. & $\square$ \\
\hline
\end{tabular} \begin{tabular}{l} 
Go to Q59 \\
Go to Q56 \\
\hline
\end{tabular}

(Only for those who answered 2 to Q55)

Would you like to use Artificial Intelligence technology and service for your business/organization in the future?

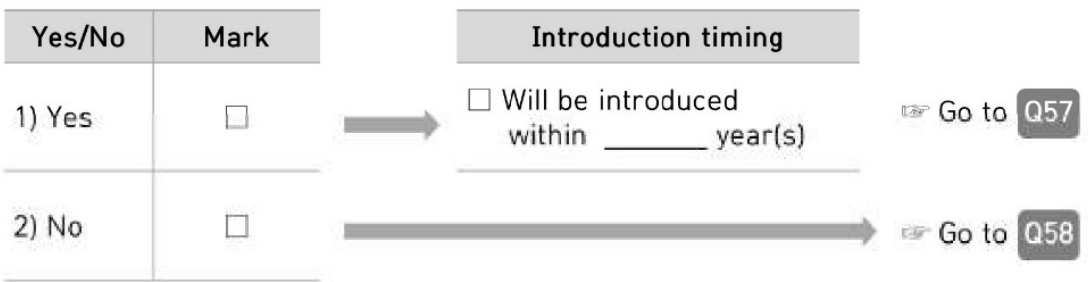


(Only for those who answered 1 to Q56)

For what purpose would you like to use Artificial Intelligence technology and service for your business/organization in the future? Pleas mark all that apply.

\begin{tabular}{l|l}
$\begin{array}{l}\square \text { 1) Cost cutting } \\
\text { - Reduce cost such as labor cost, etc. }\end{array}$ & $\begin{array}{r}\square \text { 2) Decision making support } \\
\text { - Assist with the rational decision making in } \\
\text { relation with work such as management and } \\
\text { administration }\end{array}$ \\
\hline $\begin{array}{l}\square \text { 3) Increase of productivity } \\
\text { - Reduce faults or errors when working, etc. }\end{array}$ & $\begin{array}{l}\square \text { 4) Problem solving } \\
\text { - Solve work which is difficult for human to handle }\end{array}$ \\
$\begin{array}{l}\square \text { 5) Customer reception and service } \\
\text { satisfaction }\end{array}$ & $\begin{array}{l}\square \text { 6) Creation of new revenue streams and } \\
\text { expansion of products(services) }\end{array}$ \\
\hline $\begin{array}{l}\square \text { Other } \\
\text { (Please specify : }\end{array}$ & \\
\hline
\end{tabular}

[Only for those who answered 2 to Q56]

For which of the following reasons would your business/organization not want to use Artificial Intelligence technology and service in the future? Pleas mark all that apply.

\begin{tabular}{|c|c|c|}
\hline Reasons & Explanation(Example) & Mark \\
\hline $\begin{array}{l}\text { 1) Burden of economical } \\
\text { expense }\end{array}$ & $\begin{array}{l}\text { Burden of expense for establishment and operation of system or } \\
\text { incurrence of additional cost, etc. }\end{array}$ & $\square$ \\
\hline $\begin{array}{l}\text { 2) Concern about security } \\
\text { and ethical issues }\end{array}$ & Security accident(hacking, etc.), ethical problems, etc. & $\square$ \\
\hline $\begin{array}{l}\text { 3) Complexity of } \\
\text { service(technology) }\end{array}$ & $\begin{array}{l}\text { Complexity and difficulties of technology used to establish Artificial } \\
\text { Intelligence }\end{array}$ & $\square$ \\
\hline $\begin{array}{l}\text { 4) Lack of professional } \\
\text { workforce }\end{array}$ & $\begin{array}{l}\text { Lack of professional workforce that can use AI technology and } \\
\text { service }\end{array}$ & $\square$ \\
\hline $\begin{array}{l}\text { 5) Lack of linkage with the } \\
\text { existing system and } \\
\text { process }\end{array}$ & $\begin{array}{l}\text { Declined utilization because the new process established for using } \\
\text { AI technology/service is not corresponded to the existing work } \\
\text { practice and process, etc. }\end{array}$ & $\square$ \\
\hline $\begin{array}{l}\text { 6) Insufficient data that is } \\
\text { worthy of learning }\end{array}$ & Declined utilization due to the lack of data that is worthy of learning & $\square$ \\
\hline 7) Inadequate result quality & $\begin{array}{l}\text { Weak value of utilization due to low expectation level for solvability } \\
\text { of Artificial Intelligence }\end{array}$ & $\square$ \\
\hline $\begin{array}{l}\text { 8) Lack of interest of the } \\
\text { management }\end{array}$ & Lack of interest and the management's will to invest & $\square$ \\
\hline 9) Lack of necessity & $\begin{array}{l}\text { Lack of work which will create a positive effect by introducing } \\
\text { Artificial Intelligence }\end{array}$ & $\square$ \\
\hline 10) Other & Please specify: ( & $\square$ \\
\hline
\end{tabular}

Source: 2018 Yearbook of Information Society Statistics, Ministry of Science and ICT, National Information Society Agency, 2019. Available at:

https://eng.nia.or.kr/common/board/Download.do?bcldx=20512\&cbldx=31975\&fileNo=1 
Detailed results for the AI module are provided pp. 344-357 of 2018 Yearbook of Information Society Statistics, Ministry of Science and ICT, National Information Society Agency, 2019, Korean version of the publication. Available at:

https://www.nia.or.kr/site/nia_kor/ex/bbs/View.do?cbIdx=62156\&bcIdx=20496\&parentSeq=20496

\section{Sweden $^{11}$}

\section{Statistics Sweden, ICT Usage and E-commerce in Enterprises survey 2020}

\section{Did your enterprise use AI-based software or hardware during 2019?}

The question concerns both self-developed and purchased software or hardware or access to a service, e.g. via cloud services. The activity does not have to be completed / implemented.

Do not include use of standard software, such as search engines, personal virtual assistants, smartphone apps etc.

\section{Yes No}

a) To develop or increase knowledge of customers or users (e.g. use of chat robots for customer service, products or service recommendations, to automatically improve and create content)

b) To develop a new product or service

c) To improve an existing product or service

d) To develop or improve internal processes (e.g. process flow optimisation, screening job seekers)

e) Other, please specify

The enterprise did not use AI-based software or hardware

Were any of the following factors hampering your enterprise's use of AIbased software or hardware during 2019?

Select one response for each line.
a) Knowledge of existing technologies and applications
b) Employees' skills, training or experience
c) Compatibility with existing software or hardware
d) Data (e.g. quality issues, lack of data)
e) Opportunity to experiment

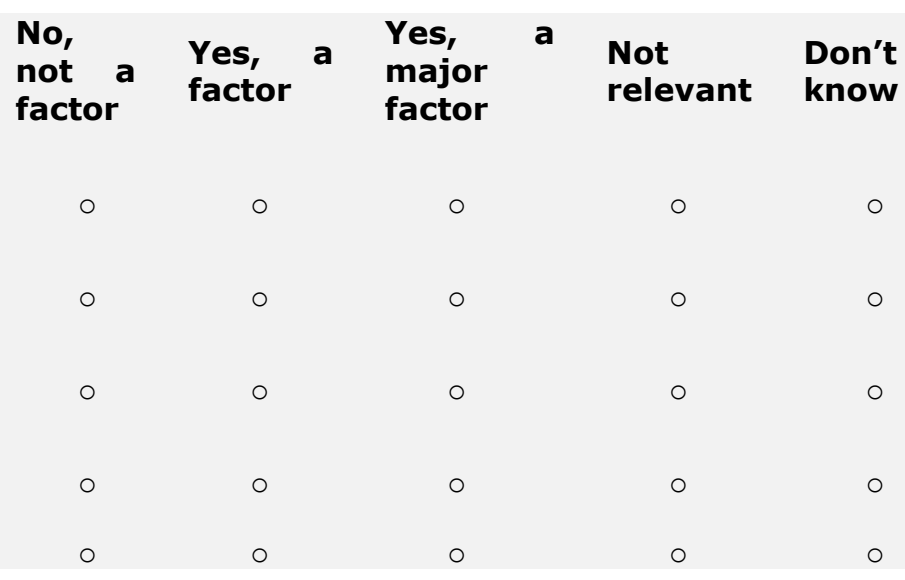


f) Enterprise's vision or AI strategy

g) Services or equipment costs

h) Data security or data integrity

i) Legal or ethical issues

j) Other, please specify

Statistics Sweden, Enterprises' IT expenditure survey 2020

What percentage of the enterprise's IT expenses and investments was relat AI-based software or hardware during 2019?

Include all expenses and investments that the enterprise has made to enable the use of $A I$.

If the enterprise did not have any expenses for AI, please enter 0 as an answer. $\%$

\section{What percentage of the enterprise's expenses for purchased IT services was related to AI-based solutions during 2019?}

If the enterprise did not have any expenses for AI, please enter 0 as an answer.

\section{Percent}
A) IT services purchased from external suppliers $\%$

B) IT services purchased within the group/franchise $\%$

Statistics Sweden, Research and development in business enterprise sector survey 2020

Based on your answers to question B1, specify R\&D costs and investments in AI, as a percentage of your total R\&D. If you did not have any AI costs or investments, enter 0.

You may make an estimate.

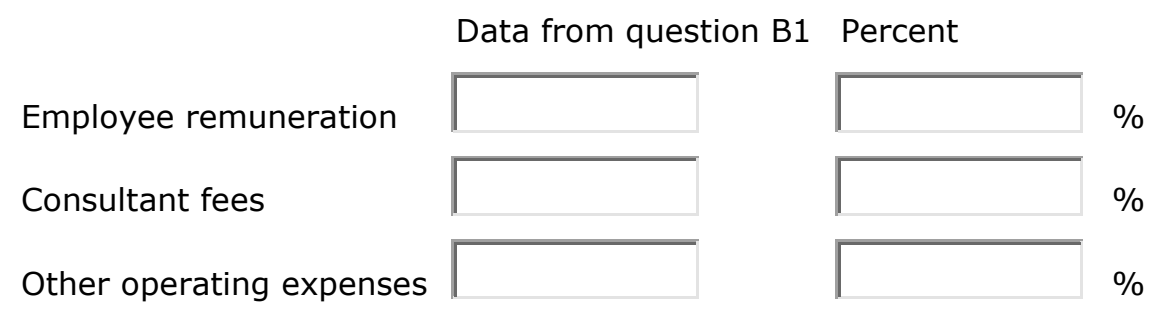


48 | AI MEASUREMENT IN ICT USAGE SURVEYS: A REVIEW

Investments

$$
0
$$

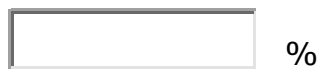

Number of full-time equivalents (FTEs) in AI among your employed personnel. You may make an estimate. The number of FTEs should relate to employee remuneration. Employee remuneration for R\&D in AI

\begin{tabular}{|l|l|l|}
\hline Women & Men & Total thousand SEK \\
\hline & & \\
\hline
\end{tabular}

\section{Number of FTEs in AI among consultants and outsourced personnel.}

You may make an estimate. The number of FTEs should relate to the costs of consultants and outsourced personnel

Cost of external personnel/consultants in AI___ thousand SEK

\begin{tabular}{|l|l|l|}
\hline Women & Men & Total \\
\hline & & \\
\hline
\end{tabular}

\section{United States}

The joined US Census Bureau and Department of Commerce 2019 Annual Business Survey detailed questionnaire is available online at:

https://www2.census.gov/programs-surveys/abs/information/abs 2019.pdf 


\section{Annex B. OECD Al principles}

Five values-based principles for the responsible stewardship of trustworthy Al:

1. Al should benefit people and the planet by driving inclusive growth, sustainable development and well-being.

2. Al systems should be designed in a way that respects the rule of law, human rights, democratic values and diversity, and they should include appropriate safeguards - for example, enabling human intervention where necessary -to ensure a fair and just society.

3. There should be transparency and responsible disclosure around Al systems to ensure that people understand Al-based outcomes and can challenge them.

4. Al systems must function in a robust, secure and safe way throughout their life cycles and potential risks should be continually assessed and managed.

5. Organisations and individuals developing, deploying or operating Al systems should be held accountable for their proper functioning in line with the above principles.

Five recommendations to governments:

1. Facilitate public and private investment in research \& development to spur innovation in trustworthy Al.

2. Foster accessible Al ecosystems with digital infrastructure and technologies and mechanisms to share data and knowledge.

3. Ensure a policy environment that will open the way to deployment of trustworthy Al systems.

4. Empower people with the skills for Al and support workers for a fair transition.

5. Co-operate across borders and sectors to progress on responsible stewardship of trustworthy Al. 


\section{Notes}

${ }^{1}$ From the Community Survey on ICT Usage and E-commerce in Enterprises 2021, version 1.2 final, as of April 15, 2020.

2 The Swedish Al definition could still be subject to change right up until the survey is disseminated in March 2020.

${ }^{3}$ Information based on telephone meeting with the SCB project manager for the Al modules January $29^{\text {th }}$, 2020.

4 The 2019 Survey of Innovation and Business Strategy (Statistics Canada), not covered in this paper, similarly includes a question on the use of $\mathrm{Al}$ among advanced technologies and has introduced a question asking the enterprises if they had had employees with programming skills in Al.

${ }^{5}$ The last part of the 2019 Annual Business Survey Questionnaire, considered Al within firms not from the usage perspective but as a technology sold by the firm, either directly or within products and services. This last part is not taken into consideration in the present paper.

${ }^{6}$ It should be noted that the list of countries is not exhaustive and should be updated when information become available

${ }^{7}$ Cross-national data collection of this type of indicator will need to face differences of regulation within countries (e.g. GDPR).

${ }^{8}$ Artificial Intelligence Strategy 2018, page 8.

${ }^{9}$ The OECD Network of Experts on AI (ONE Al) provides policy, technical and business expert input to inform OECD analysis and recommendations. It is a multi-disciplinary and multi-stakeholder group (https://oecd.ai/network-of-experts).

${ }^{10}$ Between 2017 and 2018, the section on Artificial Intelligence of the Questionnaire stay unchanged.

${ }^{11}$ The approved English translation of Statistics Sweden's Al questions were made available too late to be incorporated into the body on the comparative analysis and are provided here only for information. The SCB Al questions originate in the following surveys: ICT Usage in Enterprise, Enterprises' IT Expenditure and $R \& D$ in the Business Enterprise Sector. The comparative analysis is based the Swedish Digitalisation Council Draft Report Pilot 2018. 